\title{
Salinity tolerance mechanisms and their breeding implications
}

\author{
Mandeep Singh ${ }^{1 *} \mathbb{D}$, Usha Nara', Antul Kumar ${ }^{2}$, Anuj Choudhary², Hardeep Singh ${ }^{3}$ and Sittal Thapa ${ }^{1}$
}

\begin{abstract}
Background: The era of first green revolution brought about by the application of chemical fertilizers surely led to the explosion of food grains, but left behind the notable problem of salinity. Continuous application of these fertilizers coupled with fertilizer-responsive crops make the country self-reliant, but continuous deposition of these led to altered the water potential and thus negatively affecting the proper plant functioning from germination to seed setting.

Main body: Increased concentration of anion and cations and their accumulation and distribution cause cellular toxicity and ionic imbalance. Plants respond to salinity stress by any one of two mechanisms, viz., escape or tolerate, by either limiting their entry via root system or controlling their distribution and storage. However, the understanding of tolerance mechanism at the physiological, biochemical, and molecular levels will provide an insight for the identification of related genes and their introgression to make the crop more resilient against salinity stress.

Short conclusion: Novel emerging approaches of plant breeding and biotechnologies such as genome-wide association studies, mutational breeding, marker-assisted breeding, double haploid production, hyperspectral imaging, and CRISPR/Cas serve as engineering tools for dissecting the in-depth physiological mechanisms. These techniques have well-established implications to understand plants'adaptions to develop more tolerant varieties and lower the energy expenditure in response to stress and, constitutively fulfill the void that would have led to growth resistance and yield penalty.
\end{abstract}

Keywords: Salinity tolerance, Ion homeostasis, Novel biotechnological approaches, GWAS, Heat shock proteins

\section{Background}

Global food demand is continuously increasing, and with skyrocketing population, it is expected to double in the near future. Feeding the world population with the available limited natural resources is not an easy task [1-3]. Attributed to several biotic and abiotic stresses, genetic potential of the crops is not fully exploited. Abiotic stresses encompass raised salinity, temperature and drought, alleviation in soil oxygen, pollutants, high UV radiation, and inadequate mineral nutrients [3, 4]. Breeding approaches provide an insight for salinity stress

\footnotetext{
*Correspondence: mandeepsingh91483@gmail.com

1 Department of Plant Breeding and Genetics, Punjab Agricultural

University, Ludhiana, Punjab 141004, India

Full list of author information is available at the end of the article
}

tolerance as reported in some crops such as rice [5] and wheat [6]. Integration of comparative, functional, and structural genomics would boost the traditional breeding efforts. Genetic manipulation methods have been utilized in crop plants to recognize genes related to salt tolerance and their introgression [7].. Utilization of molecular tools in breeding programs is the most valuable upshot of biotechnology $[8,9]$. However, an enormous space between the crop yields in stress conditions and optimal conditions is still leftover.

Salinity stress is a physiological outcome of excessive salt in plant cell which has detrimental effects on plant's metabolism. Soils are stratified as saline when the ECe (Electrical Conductivity of a saturated soil Extract) is $\geq 4 \mathrm{dS} / \mathrm{m}$ which is roughly equivalent to $40 \mathrm{mM} \mathrm{NaCl}$ and approximately give rise to osmotic pressure of 0.2 
megapascal (MPa) [10]. However, plants have numerous morphological (early flowering, prevention of lateral shoot development, and root adaptations), physiological responses (stomatal responses, osmotic adjustment, $\mathrm{Na}^{+} / \mathrm{K}^{+}$discrimination, and ion homeostasis), and biochemical responses (antioxidant activity, polyamines, change in hormone level, increased proline level) under salinity stress, forming it as a complex phenomenon [1113]. Abscisic acid (ABA) is a major phytohormone which plays a significant role in improving the performances of plants during stress conditions such as salinity, low temperature, and drought [14]. ABA production in the plants alleviates the effects of salinity on the growth, translocation of assimilates, and photosynthesis [15, 16]. Application of sodium nitroprusside (SNP) in soybean (Glycine $\max$ L.) enhances the physiological and morphological attributes under saline conditions. It has been reported that SNP as nitic oxide (NO) donor could greatly increase the salinity tolerance and regeneration potential by mimicking of plant hormone and signal molecule [17].

Soil salinity typically inhibits plant growth and reproduction through an initial osmotic stress phase followed by ionic toxicity due to accumulation of $\mathrm{Na}^{+}$ and $\mathrm{Cl}^{-}$ions in the cell cytosol that results ultimately in oxidative stress and nutritional deprivation $[18,19]$. Reactive oxygen species (ROS) scavenging, ion homeostasis, osmotic adjustments, and metabolic activities are greatly affected when plants are subjected to salinity stress. In order to overcome these various abiotic stresses, plants accumulate compatible harmless biomolecules which play a significant role in plant processes. These include polyamines [20, 21]; heat shock proteins (HSPs) [21, 22]; nitric oxide (NO) [23, 24]; and hormones like ABA [14, 25], salicylic acid [26], and brassinosteroids [26, 27]. Late embryogenesis abundant (LEA) protein is found to be effective against various stresses such as cold, drought, and salinity [28, 29]. These accumulated solutes have a role in protein solubilisation like glycine, ectoine, and betaine and in uncharged solutes such as pinitol and mannitol which have a scavenging activity of ROS [21]. NO is a vaporous molecule having a significant role in the regulation of several developmental processes (cell death, seed germination, stomata closure, root growth, flowering, and respiration), plant growth, and response to stress and a role in signal transduction [23] (Fig. 1).

Various traits have been identified in several studies for which expression or presence connecting the plant adaptability to salinity stress conditions (Table 1). Genomic approaches and crop physiology provide new insights to breeders to overcome salinity stress using new emerging tools for crop improvement [9]. Plants cope with salinity stress using various mechanisms, and these mechanisms can be exploited using strategies as mentioned above.

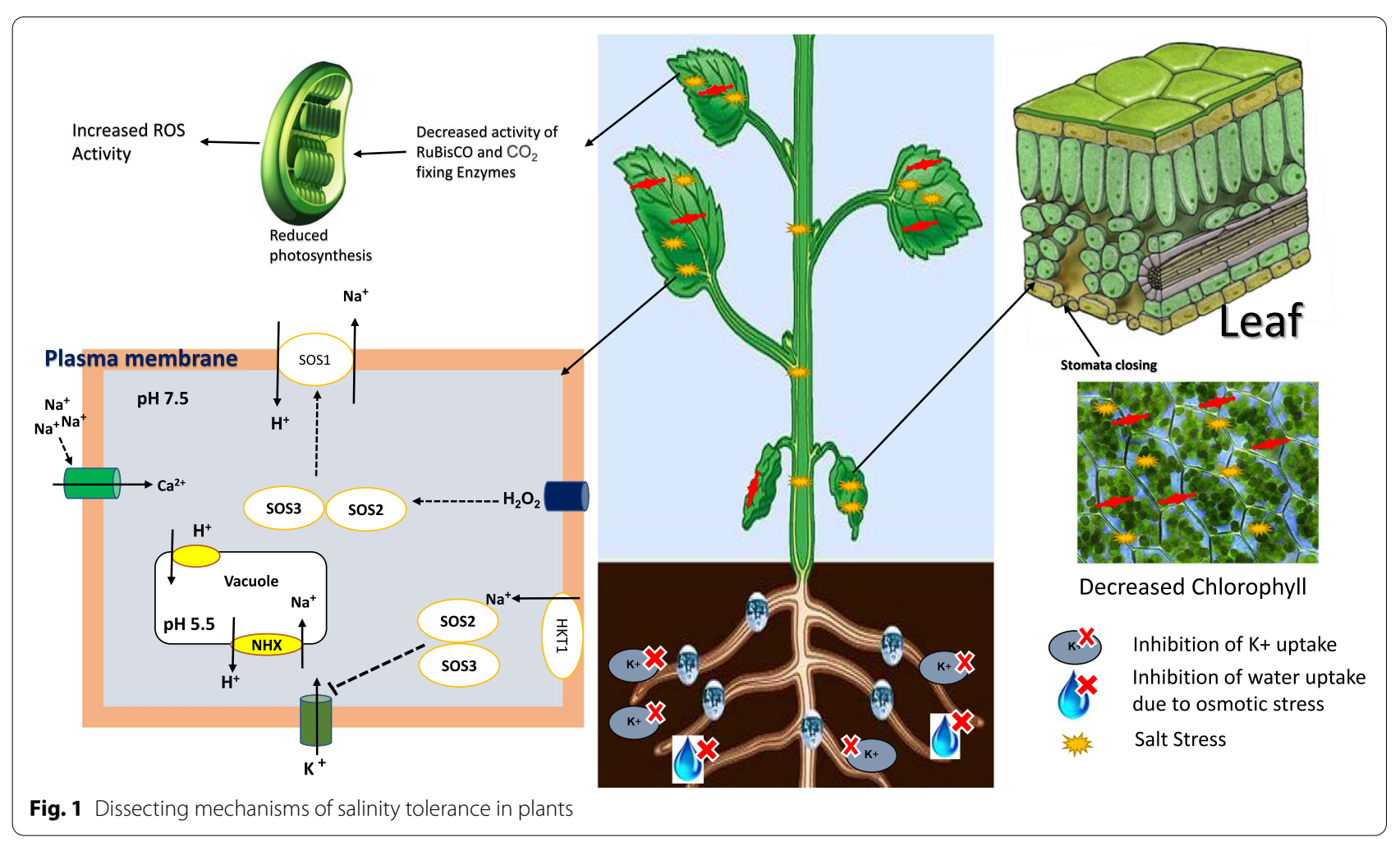




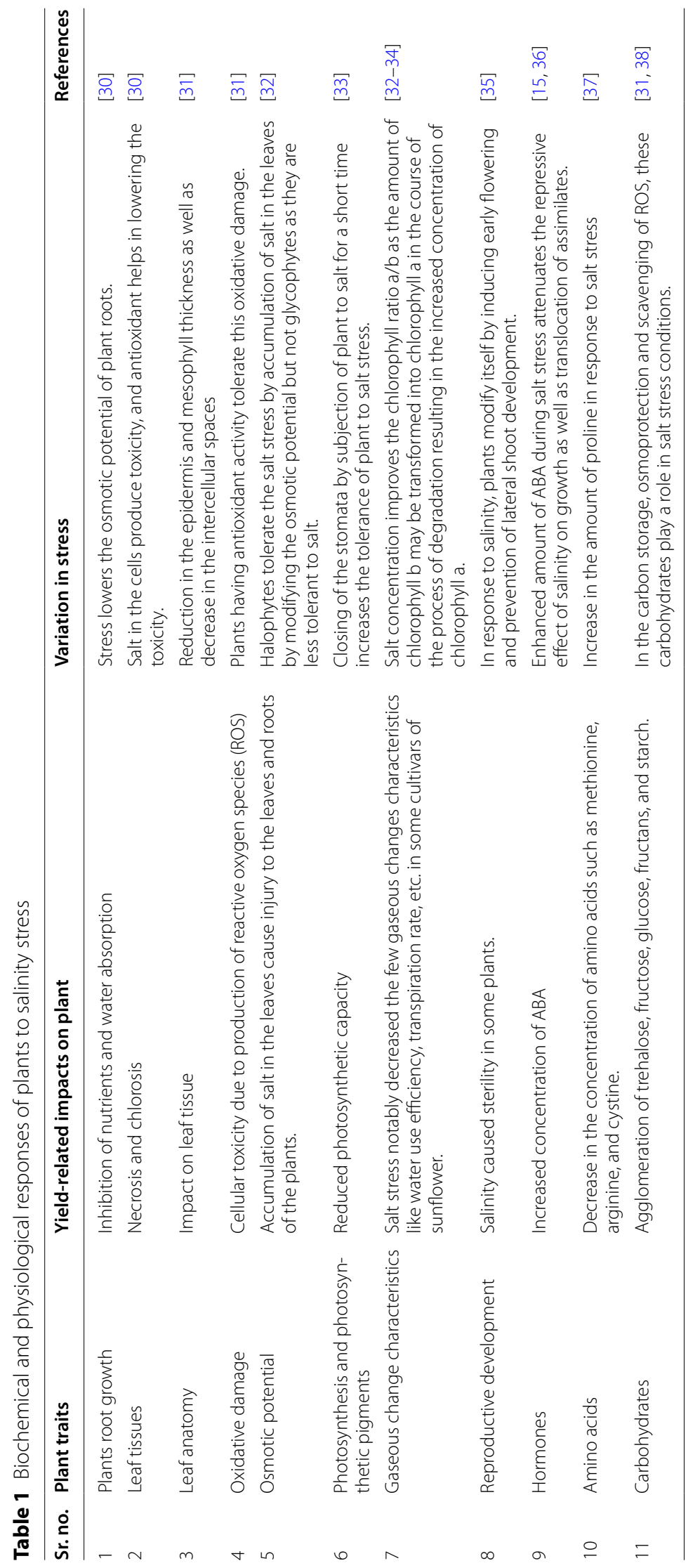


This paper emphasized salinity stress, its effect on plants, and their adaptive mechanisms and discussed new cutting-edge tools to cope with salinity stress in this era where food security is the major challenge.

\section{Main text}

\section{Physiological aspects of salinity tolerance}

Tolerance to salinity is the plant's potential to grow and flourish its life cycle in high saline conditions [11]. Salinity tolerance in crops varied according to the crop type. For example, barley is more tolerant to salt than rice, legumes are severe sensitive than cereals, and adequate salinity tolerance is there in case of Lucerne and Alfalfa [39]. The most deleterious effect imposed by salinity stress is ion toxicity. Ebrahim et al. [40] demonstrated that tolerance mechanisms such as ion exclusion $(\mathrm{Na})$ present in the wild barley (Hordeum vulgare) cause much lower accumulation of $\mathrm{Na}$ in the root and shoot and better $\mathrm{K} / \mathrm{Na}$ discrimination than in the cultivated barley, resulting in the higher survival rate under $300 \mathrm{mM} \mathrm{NaCl}$ for 4 weeks. When two chickpea varieties (Rupali and Genesis 336) subjected to salt stress were compared, they exhibited alleviated sugar content and presence of inositol, galactitol, mannitol, arabitol, xylitol, and erythritol, suggesting their roles under salt stress. In another study, inositol and sucrose were found to be highly accumulated in Atriplex halimus leaves under salt stress. Moreover, in Casuarina glauca, trehalose concentration significantly enhanced in roots at both 400 and $600 \mathrm{mM} \mathrm{NaCl}$ and simultaneously decreased carbohydrates such as fructose, sucrose, and glucose under salt stress [41, 42].

Vacuoles have a potential role in plant cell functioning. Salinity stress was the major challenge during the evolution of terrestrial plants [43]. SV (slowly activated vacuolar channels) are the most copious ion channels in vacuoles of plants, and these channels were the first discovered channels [44]. The crystallographic structure of SV channels has been published in 2016 from Arabidopsis thaliana $[45,46]$. To prevent the salt from reaching the leaf surface, plants adopt two techniques. Salt ions either pass into the vacuole or get collocated in the apoplast. The amount of salt ions should not exceed the quantity accumulated in the vacuole [47].

Osmotic adjustment is a physiological adaptation of the plants that have drawn attention from past several years in response to salinity stress [13, 48]. Studies on physiological responses reveal that Cakile maritima species show responses to salinity stress through the mechanism of osmotic adjustment and selectivity of potassium ion over sodium ion $[49,50]$. For maintaining the turgidity of the cell, osmotic adaptations play a significant role which enhances the productivity of the crop and development of the plant [19]. Contradictory findings about the role of proline in salinity tolerance have been reported. A markedly higher accumulation of proline took place in the leaf tissues of the salinity-sensitive cultivated than that of the wild barley genotype [40] and a nonsignificant contribution of proline in the salinity tolerance of Aegilops cylindrica species [51] observed at high levels of $\mathrm{NaCl}$ treatments. The puzzling differences in the literature regarding the contribution of proline to salinity tolerance can be explained by several facts: (1) the duration of the treatment, (2) the intensity of salinity stress, (3) the genetic background of the tested species, (4) the physiological stage of the sampling plants, and (5) the environmental conditions in which the plant grows [18]. In addition to proline contents, among the solutes, the soluble sugar content has an impressive role in the osmotic adjustment process under abiotic stresses. In melon (Cucumis melo) cultivars exposed to salinity stress, both proline content and total sugar content were significantly increased [52]. Osmotic adjustment in some plants is accomplished by consuming excessive levels of inorganic ions $[35,53,54]$.

Salinity stress at moderate concentrations for long periods (months) or at high concentrations even in short periods (weeks) causes growth inhibition and ultimately death of the plant. Tolerance to salinity is attained through interconnected mechanisms [55]. In order to improve salinity tolerance in plants, ion and osmotic homeostasis play a significant role in stressful environmental conditions. The final decisive factor of these mechanisms includes several ion transporters which have a role in distributing toxic ions at cellular and organ levels [56]. Studies on salinity tolerance reveal an important issue to decide which transporters restrict or allow the sodium entry into the cell. A high accumulation of sodium ions in the cytoplasm restricts the enzymatic activities [57]. The vacuolar layer consists of two types of $\mathrm{H}^{+}$pump namely $\mathrm{V}$-PPase (vacuolar pyrophosphate) and V-ATPase (vacuolar type $\mathrm{H}^{+}$-ATPase) $[58,59]$. These antiporters move the excess salt from the apoplast to the cytoplasm of the cell, and sodium moves to the vacuole in order to maintain osmotic regulation [60]. V-ATPase is the reigning $\mathrm{H}^{+}$pump available in the plant cell. The stability of the plants is controlled by the activity of V-ATPase during stress conditions [35]. NHXs $\left(\mathrm{Na}^{+} / \mathrm{H}^{+}\right.$ exchangers) sectionalized the $\mathrm{Na}^{+}$into vacuoles. $\mathrm{Na}^{+} / \mathrm{H}^{+}$ antiporter is directing the partition of $\mathrm{Na}^{+}$to the vacuole, thus limiting the fixation of $\mathrm{Na}^{+}$in the cell cytoplasm. Activity of $\mathrm{Na}^{+} / \mathrm{H}^{+}$antiporter is arbitrated by the effluence of $\mathrm{Na}^{+}$from the roots of the plant which is encouraged by the SOS1 (salt overly sensitive) protein [61].

The concept of $\mathrm{Na}^{+} / \mathrm{K}^{+}$discrimination, in which uptake of $\mathrm{Na}^{+}$is exchanged by $\mathrm{K}^{+}$, allow the plant to tolerate the salinity stress. That is why the concept of $\mathrm{Na}^{+} /$ 
$\mathrm{K}^{+}$discrimination is taken into account as a significant basis in commercial crop selection. But this $\mathrm{Na}^{+} / \mathrm{K}^{+}$discrimination concept is not a basis of salinity tolerance in glycophytes. In few salt-tolerant cultivars of barley and their wild relatives, there is not any trait for $\mathrm{Na}^{+} / \mathrm{K}^{+}$discrimination [44]. Halophytes favor inclusion of $\mathrm{Na}^{+}$over $\mathrm{K}^{+}$which acts as a tool in osmotic adjustment and shows a positive correlation between salt tolerance and inclusion of $\mathrm{Na}^{+}$in plants [45]. In cytosol, plant $\mathrm{K}^{+}$requires approximately $100 \mathrm{mM}$ of $\mathrm{K}^{+}$ion for activities of cytosolic enzyme, whereas in vacuoles, $\mathrm{K}^{2+}$ ranges from 10 to $200 \mathrm{mM}$. The $\mathrm{K}^{+}$ion transport from vacuolar tissues maintains cell turgidity through membrane channels and $\mathrm{K}^{+}$transporter against the concentration gradient. In case of low $\mathrm{K}$ extracellular concentration, the affinity mechanism of $\mathrm{K}$ increases actively. As a result, $\mathrm{K}^{+}$concentration in soil favours the uptake processes. Similarly, a decreased $\mathrm{Na}^{+}$ion concentration $(1 \mathrm{mM}$ or less) is managed in the cytosolic region. Such enhanced level of $\mathrm{Na}^{+}$concentration in soil under salt stress alleviates the competition between $\mathrm{K}$ and $\mathrm{Na}$ ions for similar mechanism causing diminishing of $\mathrm{K}^{+}$uptake $[42,61]$.

Reduction in photosynthetic rate, stomatal/non-stomatal factors, deterioration in chlorophyll and carotenoid pigments, and chloroplast degradation were observed when exposed to salt stress as observed in Phaseolus vulgaris, Zygophyllum xanthoxylum, and Lycopersicum esculentum [62, 63]. Mutant studies revealed the role of ion transporters and channels in regulating chloroplast function during salt stress. The mutant lacking two chloroplast-localized $\mathrm{K}^{+}$efflux anti-transporter (KEA1 and KEA2) demonstrates lowered photosynthetic efficiency, and exposure of $\mathrm{Na}^{+}$in these mutants can improve phenotypic traits. However, chloroplasts give retrograde signals to connect chloroplast status, stimulating signalling cascade related to salinity response. In a nutshell, $\mathrm{Na}^{+}$ affects photosynthesis by degrading chloroplast function and proton motive force and by disrupting the function of $\mathrm{Co}_{2}$-functioning enzymes [61].

In halophytes, ion detoxification and osmo-protective strategies comprise $\mathrm{Na}^{+}$extrusion from the roots to the xylem cell. The vacuolar compartmentation involving NHXs causes ion transportation. Several halophytes synthesize high $\mathrm{Na}^{+}$in shoot than roots while maintaining increase in concentration of $\mathrm{K}^{+}$as compared with glycophytes, and thus maintaining $\mathrm{Na}^{+} / \mathrm{K}^{+}$ratio. The above findings confirm that halophytes employ various strategies in ion homeostasis and transportation in salinity stress condition. Similarly, recent genetic studies on the expression of HKT1 and SOS1 genes in Eutrema parvula (EpHKT1:1); AcNHX1, AcSOS1, and AcHKT1 in Aegilops cylindrica, and E. salsugineum (EsSOS1) conferred higher salt tolerance as compared with other homologous analogous AtHKT1:1 and AtSOS1 in Arabidopsis [61, 64, 65]. Apart from salinity-exclusion mechanisms, halophytes have also evolved salt-avoidance mechanisms such as excretion (salt glands, bladder hairs, and re-translocation) and succulence for sodium dilution [66].

\section{Biochemical aspects of salinity tolerance}

Plants engage different mechanisms to ensure salinity tolerance. At present, findings regarding the metabolic changes due to salinity tolerance are partial. A deep insight in metabolic as well as biochemical processes involving salinity tolerance is necessary for engineering of crop plants against salinity stress.

\section{Heat shock proteins (HSPs)}

HSPs are dispersed extensively in nature; also, these proteins pile up during stress conditions. Heat shock proteins are molecular chaperons which have a significant role in gathering and folding of proteins and eradication and destruction of non-useful proteins. Heat shock proteins are categorized in accordance to the molecular weight. These include small family Hsp, Hsp 100 family, Hsp 90 family, Hsp 70 family also known as DnaK family, and chaperonins such as Hsp60 and GroEL [67]. Salinity as well as drought stress is instigated by heat shock proteins (HSPs). Under stress conditions, several heat shock proteins are found to be upregulated such as HSP70-9-12 and -33 in poplar [68] and HSP70 in wheat [69] and rice seedlings [70]. Additionally, other heat shock proteins were upregulated in salinity stress such as HSP100-75 and -21; HSP90-12 and -9; HSP40-117 and -113; HSP60-49, -38, -33, and -31; and HSP21 in poplar [62] and HSP40 in rice [71]. Heat shock proteins such as HSP90 in Arabidopsis [22] and small HSPs, Clp (D1, D2), Clp (B1, B2), and HSP100 in rice crop [72, 73] exhibited salinity stress tolerance. Heat shock protein's role in salinity stress is genotype specific in which HSPs were instigated more in cultivars which are salinity tolerant, and these were reported in soybean [23]. Studies revealed that heat shock proteins (HSPs) are significantly involved in tolerance to salinity stress. Transgenic tobacco with HSPs of Medicago sativa showed increased salt tolerance when compared with wild types at germination stage. However, overexpression of HSP-related transcription factors alleviated heat and enhanced the susceptibility to ABA and salinity stress in transgenic Arabidopsis. Moreover, increased expression of HSP genes in $H$. vulgare have been studied in site-specific salinity stress $[53,56]$. According to Cen et al. [74], ion transport efficiency of a plasma membrane intrinsic protein gene namely HvPIP2;8 was found when Xenopus laevis was 
studied. It has also been reported that the expression of $H v P I P 2 ; 8$ significantly increased the movement of $\mathrm{Na}^{+}$/ $\mathrm{K}^{+}$salt as well as water transport, ultimately leading to salinity stress tolerance in $H$. vulgare.

Moreover, overexpression of Ipomoea batata Myoinositol-1-phosphate synthase 1 (IbMIPs1) positively stimulates salt stress in transgenic plants. The contents of $\mathrm{Na}, \mathrm{H}_{2} \mathrm{O}_{2}$, and melon dehydrogenase (MDA) directly reduced, whereas the phosphatidic acid, inositol, proline, trehalose, $\mathrm{ABA}, \mathrm{K}^{+}$, and $\mathrm{Ca}^{+}$levels significantly enhanced in transgenic I. batata under salinity stress [75]. In addition, introgression of the arginine decarboxylase gene into Lotus tenuis resulted to salinity tolerance by upregulating proline content, which maintains membrane integrity. However, transgenic Triticum aestivum containing the Choline dehydrogenase gene of $E$. coli were highly tolerant to salt stress due to enhanced Glycine betaine content in transgenic plants. Comparatively, Gossypium hirsutum contains Choline monooxygenase genes derived from Atriplex $s p$. enhancing the level of Glycine betaine in transgenic plants, resulting to membrane integrity under salinity stress [42].

HSPs are mainly confined in various cell organelles and play a key role in protein homeostasis, prevent protein folding, refolding of unfolded polypeptides, etc. when exposed to salinity stress. These proteins reduce production of ROS and prevent from oxidative damage in response to salt stress. It also prevents degradation of chloroplast structure and reduction of chlorophyll content and photosynthetic content. Specifically, HSP70 serves as an anti-apoptotic proteins and also induces programmed cell death in transgenic plants. The upregulation of HSPs helps in protection of photosynthetic machinery [76].

\section{Small ubiquitin-like modifier (SUMO) protein}

SUMO proteins come under the small protein family. Post-translational modification of the SUMO protein is SUMOylation which is having a crucial role in transcriptional regulation, stability of protein, various stress responses, apoptosis, and nuclear-cytosolic transport [77]. SUMO shows reversible nature in linkage onto substrate, and SUMO proteases have a crucial role in course of SUMOylation. OTS1 (overly tolerant to salt 1) and OTS2 (overly tolerant to salt 2) are the two SUMO protease which have been identified in the Arabidopsis thaliana to regulate responses to salinity stress [78]. The SUMO protein acts as a critical regulator in response to salinity stress in rice crop. The activity of SUMO protease has been demonstrated by the researchers for the orthologue OsOTS1 and reveals that it plays a crucial role for tolerance to salinity in rice crop [79].

\section{Polyamines (PAs)}

PAs are omnipresent, tiny, polycationic aliphatic low molecular weight molecules copiously strew in the plant kingdom and have vigorous biological activity [80, 81]. Polyamines are found to play significant roles in normal growth, seed germination, and development such as cell proliferation regulation, morphogenesis, differentiation, breaking of dormancy, somatic embryogenesis, etc. [20,82]. Most wonted polyamines are triamine spermidine (SPD), tetra-amine spermine (SPM), and diamine putrescine (PUT) $[45,83]$. Out of these polyamines, diamine putrescine is the smallest one and is made from either ornithine or arginine [20, 84]. External application of polyamines (PAs) mainly SPD and SPM results in the enhancement of photosynthesis and reactive oxygen metabolism which ultimately improve the growth of the plant and alleviate the salt effect $[85,86]$. Analogous results have also been attained in the seedling study of soybean crop [87]. Various metabolic pathways are found to be affected by the PAs namely SPD and SPM [88]. ABA and polyamines in combination helps in reducing the effect of salt in seedlings of grape [89].

The alleviated activities of phospholipase C (PLC) and phospholipase D (PLD) were observed in rice and Arabidopsis, when exposed to salt stress. Biosynthesis of PAs stimulates downstream regulation of $\mathrm{Ca}^{2+}$. The $\mathrm{Ca}^{2+}$-independent $\zeta$-type PLD affects the movements of root growth toward salt-prone sites. Additionally, PA itself influences the regulation and movement of auxin and abscisic acid, two phytohormones induced during salt stress conditions. However, PAs also affect $\mathrm{Na}^{2+}$ transport via mitogen-activated protein kinase (MAPK6), that influences downstream regulation of NHX7/SOS [90]. In another study, rice MAPK6 regulates downstream activity of effector-like lectin RLK Salt I, Intolerance 1 and dephosphorylated through enzyme like protein phosphatase $2 \mathrm{~A}$ and ultimately affect salt sensitivity and ethylene homeostasis. More precisely, PAs elicit activation and localization of stress-related proteins and osmolyte, thereby simulating $\mathrm{Na}^{2+}$ transport and hormone signalling $[62,91]$.

\section{Antioxidants}

Oxygen is a statutory constituent in the plants and is related with some processes like oxidative phosphorylation, metabolism, and mitochondrial respiration to provoke energy. In the course of the metabolic process, oxygen is transformed into ROS (reactive oxygen 
species). ROS constitutes hydroxyl radical, hydrogen peroxide, singlet oxygen, etc., and concentration of these ROS enhance during salt stress resulting in the cell death, irreversible metabolic dysfunction, and cytoplasmic membrane damage [92].

SOD (superoxide dismutase) has the ability to eliminate the large amount of superoxide anions from the cells and therefore acts as a defense system for salinity stress. These SODs are categorized into three classes. These classes are copper/zinc SOD (Cu/Zn-SOD), manganese SOD (Mn-SOD), and iron SOD (Fe-SOD). The superoxide anions can dismutase into the $\mathrm{H}_{2} \mathrm{O}_{2}$ and $\mathrm{O}_{2}$ with the help of SOD that eradicate the toxicity of superoxide [93]. CAT (catalase) is an enzyme which is present in peroxisomes and it deplete the amount of $\mathrm{H}_{2} \mathrm{O}_{2}$. High empathy for hydrogen peroxide makes it different from APX (ascorbate peroxidase), and it entails a reductive substrate. Catalase (CAT) eliminates the hydrogen peroxide $\left(\mathrm{H}_{2} \mathrm{O}_{2}\right)$ which is formed by light reaction [94]. APX is an important enzyme which helps in the elimination of hydrogen peroxide. APX eliminates the hydrogen peroxide $\left(\mathrm{H}_{2} \mathrm{O}_{2}\right)$ from the cell which is produced in the chloroplast by Miller reaction [95]. External application of ascorbate to different plant species helps to alleviate the inauspicious effect of salt stress [96, 97]. In Arabidopsis, salt stress-stimulating production of apoplastic reactive oxygen species (ROS) including hydroxyl radicals, superoxide, singlet oxygen, and hydrogen peroxide influences oxidative damage and disrupts redox potential. The expression of Respiratory Burst Oxidase Homologs $(R B O H s)$ genes is stimulating dynamically, and they liberate salt-generated ROS waves. Under salt stress, these complicating ROS biosynthesis and production network are active constantly and play salt tolerance response [62]. Under salt stress, the amino acid concentration increased in two salt susceptible lines and three salt tolerance lines in Oryza sativa. Leucine, phenylalanine, isoleucine, and proline contents were enhanced among five lines. A recent study showed that the levels of $\alpha$-aminobutyric acid, glycine, leucine, threonine, alanine, and serine glutamate reduced, whereas citrulline, ornithine, aspartic acid, cysteine, ornithine, valine and proline levels were significantly enhanced in Cucumis sativa when exposed to salinity stress [98].

Similarly, flavonoids including quercetin 3,30,7-triO-sulphate, cyanidine, quercetin, luteolin cyanidine 3 -arabinoside chloride were significantly enhanced in soyabean roots in salt stress [99]. Metabolomics and quantitative phosphoproteomic studies revealed that MYB 17 optimizes flavonoid metabolism in Glycine max under salinity stress conditions. According to $\mathrm{Xu}$ et al. [100], activities of flavonoids associated such as flavonol synthase $(A v F L S)$, flavanone 3-hydroxylase $(A v F 3 H)$, and flavonoid 30-hydroxylase $(A v F 30 H)$ genes were upregulated in Apocynum venetum seedlings under salt stress. Similarly, in Zea mays, cell wall content was reported to have decreased lignin, cellulose, and matrix polysaccharides in both shoot and root regions [101].

Dimethylsulfonium compounds contribute in the maintenance of protein integrity and ROS scavenging under salt stress. Glycine betaine as an osmoprotectant significantly improves proline content so effectively, and enhanced glutathione peroxidase and glutathione$\mathrm{S}$-transferase leads to the reduction of membrane peroxidase in different crop plants (rice and barley). Besides these, asparagine, sucrose, and glycine betaine contents significantly increased in maize shoots, whereas aspartic acid, malic acid, and $\gamma$-aminobutyric acid in roots when exposed to high salt stress $[44,102]$.

Recently, in Solanum lycopersicon, exposure of melatonin enhanced plant growth, carbohydrate content, and chlorophyll content and alleviated the enzymatic activities of ribulose-1,5 bisphosphates and carbonic anhydrase; these were recorded under salt stress. Additionally, melatonin exposure improves osmoregulation by alleviating activities of proline, soluble sugars, and other stressdependant enzymes $[62,103]$.

According to Cen et al. [74], exogenous application of melatonin significantly improves $\mathrm{H}_{2} \mathrm{O}_{2}$ scavenging and increases antioxidant enzymes in Medicago sativa under salt stress conditions. Similar findings were reported by Quan et al. [104], that tolerant $M$. sativa exhibits reduction in accumulation of ROS as well as lower risk of membrane damage than salt-sensitive types. In another study, protein oxidation and lipid peroxidation occur in the apoplastic region when exposed to high salt condition. An enhancement in POX levels lowers $\mathrm{H}_{2} \mathrm{O}_{2}$ using different substrates, whereas activities of ascorbate peroxidase, catalase, and superoxide dismutase were increased in salt-tolerant $M$. sativa [105].

Kiani et al. [106] studied the antioxidant and protective role of polyphenol against salinity stress and the differential responses of genotypes using highly salt-tolerant, moderately salt-tolerant, and salt-sensitive genotypes. The vigorous antioxidant activity and robust accumulation of phenolic compounds in the leaves of the male parent (Ae. cylindrica Host) and amphidiploid derivates would imply greater sophistication in genetic diversity for the evolvement of defense-oriented strategies to prevent the accumulation of intracellular free radicals generated under salt stress.

\section{Gene expression and salinity}

Molecular responses to abiotic stress consist of a number of genes and signalling cascades which are highly regulated and facilitate the crop plants to cope with the stress 


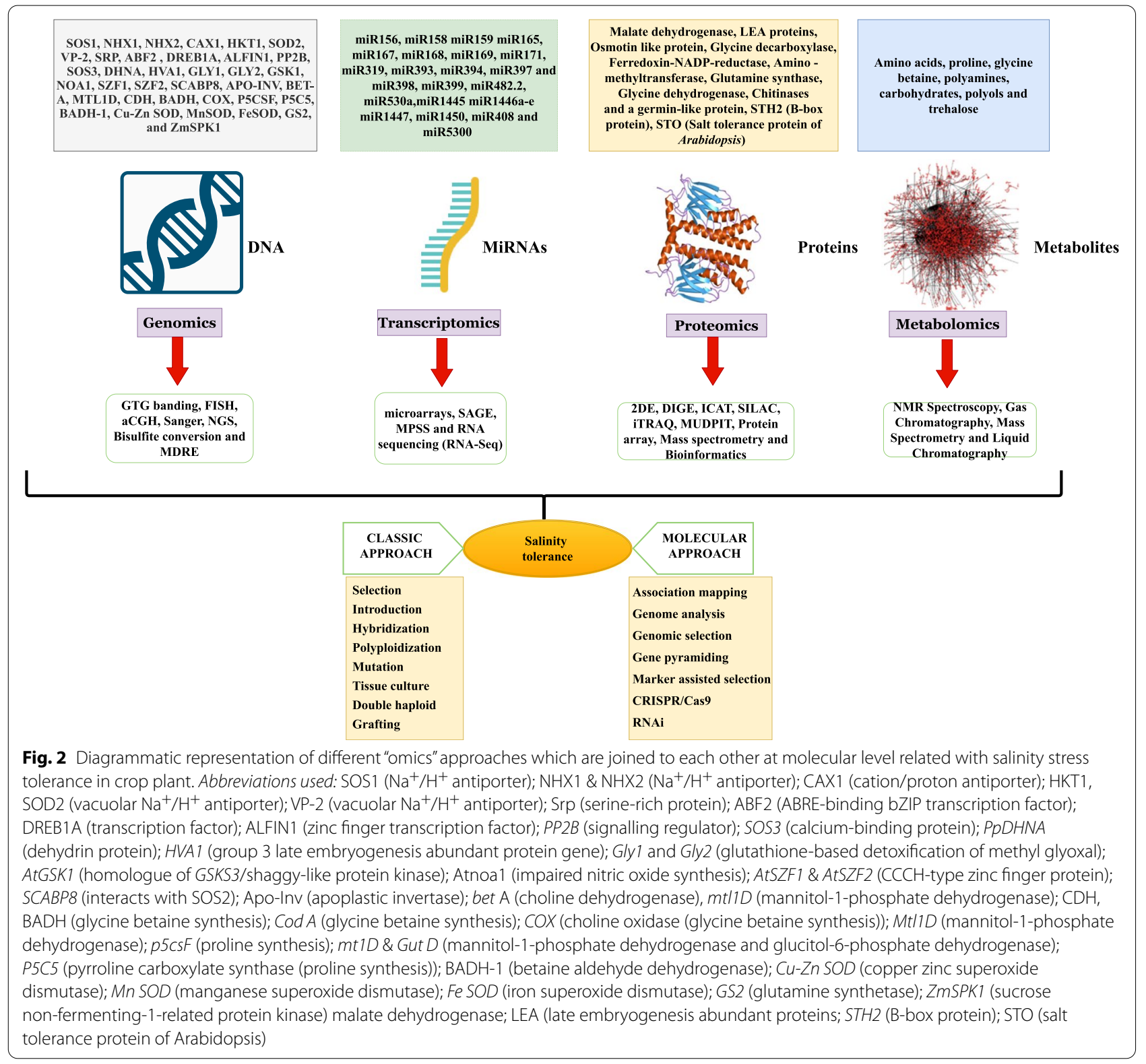

conditions. Regulation is mostly at transcriptional, posttranscriptional, and post-translation levels, but the main emphasis is at the transcriptional level which includes chromatin remodelling and upregulation and downregulation of the coding regions of the gene [107, 108]. Salinity tolerance is a composite and quantitative genetics process which is controlled by several number of genes $[52,109]$. Several transcription factors as well as saltresponsive genes have been recognized with the help of genomic and transcriptomic approaches (Fig. 2). Among the gene families, it has been found that the SOS gene family plays a crucial role in response to salt stress in ion homeostasis [110].
Physiological responses to stress exhibit recent progresses in molecular work which show the detection of several genes having a role in salinity stress (Table 2). Transcription factors are assessed as principal regulators which have a key role in controlling the expression of genes. Dehydration responsive element binding (DREB), NAC, APETALA2 (AP2), C2H2, WRKY, and bZIP (basic leucine zipper protein) families of transcription factors consist a huge number of members for stress-responsive genes. The $b Z I P$ gene expression has been observed by the scientist showing the upregulation of genes in wheat variety which is salt sensitive, but there is a downregulation of genes in the salt-tolerant variety of wheat [51]. 
Table 2 Involvement of genes in functional aspects and mechanism of salinity tolerance

\begin{tabular}{|c|c|c|c|c|}
\hline Sr. no. & Genes & Function during salt stress & Mechanism of action & References \\
\hline 1 & sosi & $\begin{array}{l}\text { Transport of sodium ion from root to shoot of the } \\
\text { plant }\end{array}$ & $\begin{array}{l}\text { The protein of SOS } 1 \text { gene acts as antiporter of } \\
\text { plasma membrane } \mathrm{Na}^{+} / \mathrm{H}^{+} \text {. }\end{array}$ & [111] \\
\hline 2 & sos2 & Protein kinases & $\begin{array}{l}\text { C terminal domain of SOS2 associates with salt stress } \\
\text { evoked } \mathrm{Ca}^{2+} \text { via NAF domain (also called as FISL } \\
\text { motif). }\end{array}$ & {$[112]$} \\
\hline 3 & sos3 & Calcium-binding protein & $\begin{array}{l}\text { SOS protein as well as } \mathrm{Ca}^{2+} \text { behave as intonation of } \\
\text { intracellular } \mathrm{Na}^{+} \text {homeostasis. }\end{array}$ & [113] \\
\hline 4 & ERF1 (SERF1) & Improve salinity tolerance & $\begin{array}{l}\text { SERF1 gene attaches with the promoter region of } \\
\text { MAP 3K6, MAPK5 to show tolerance against salinity } \\
\text { stress. }\end{array}$ & {$[114]$} \\
\hline 5 & HVP1 and HVP10 & Expressed during salinity stress & $\begin{array}{l}\text { These two genes express itself in the presence of } \\
\text { ABA in Hordeum vulgare. }\end{array}$ & [115] \\
\hline 6 & TIP1 and GLPI & Expressed upon salt stress & $\begin{array}{l}\text { Treatment of ABA on the wheat plant shows the } \\
\text { expression of these genes against salt stress. }\end{array}$ & [116] \\
\hline 7 & $r d 29 A$ & Act with $D R E B 2 A$ transcription factor & $\begin{array}{l}\text { This transcription factor DREB2A is induced by salt } \\
\text { stress in the Arabidopsis plant. }\end{array}$ & {$[117]$} \\
\hline 8 & TaWRKY2, TaWRKY19 & Improved salt tolerance & $\begin{array}{l}\text { Overexpression of these genes improve salt toler- } \\
\text { ance by enhancing the downward expression of } \\
\text { genes RD29B and STZ. }\end{array}$ & [118] \\
\hline 9 & OsClCa & Decrease in the salt concentration in the rice plant & $\begin{array}{l}\text { This gene acts through the leaves and roots of } \\
\text { the plant, and there is decrease in the transcript } \\
\text { accumulation in the variety of rice IR } 29 \text { which is salt } \\
\text { sensitive. }\end{array}$ & [119] \\
\hline
\end{tabular}

Abbreviations used: SOS1 salt overly sensitive 1, SOS2 salt overly sensitive 2, SOS3 salt overly sensitive 3, ETF1 ethylene response factor 1, HVP hordium vulgare vacuolar $\mathrm{H}+$-pyrophosphatase, GLP-1 glucagon-like peptide-1, TIP-1 tip elongation protein 1, Rd29A response-to-dehydration 29A, OsCLCa Oryza sative chloride channel-a, TaWRKY transgenic tobacco WRKY

The NAC family of transcription factors shows the overexpression of genes in wheat and rice crop resulting in the salinity tolerance by the plants thus have key role in alleviating the effect of stress. Some of the transcription factors are modulated by various kinases which have a crucial role in the adaptation of plants to salinity stress. It has been reported that transcription factor OsRMC (Oryza sativa root meander curling) in rice crop coding for receptor-like kinases which is explained as a pessimistic regulator for response to salt stress. It is also reported that the transcript level of gene OsERBP1 is not influenced by salt, severe cold, or ABA significantly, but it is only regulated faintly by moderate cold and drought.

\section{Breeding strategies}

Many researchers have been studying breeding for tolerance to salt [120-122]. There have been many investigations in screening and breeding for salinity tolerance in crop plants, and the subject has been reviewed by several authors [123-126]. With the advancement in genetic inheritance, evaluation techniques, software techniques, molecular markers, modification of germplasm and mapping, it facilitates the improvement in salt tolerance and other abiotic stresses [127]. Majority of the plant processes which are having a role in salinity tolerance show continuous diversity, have a little inheritance, and are also affected by environmental factors [26, 121].

\section{Mutation breeding}

Mutation breeding, a tool for creating genetic variation, is useful for crop improvement. A key point in mutation breeding is identification of individuals with a target mutation involving two major steps: screening and confirmation of mutants [128]. In mutation breeding, the seeds are treated with mutagen (agents such as gamma rays, chemical mutagens, X-rays, and fast neutrons) and grown further for segregation and the plants with useful traits are selected to grow next generation. Multi-location trials are conducted for evaluation and released as a new variety with use [129]. Studies have been done to improve the salinity tolerance in plants. There is an evidence of salt oversensitivity which is achieved through mutation breeding in barley crop that show improvement in salinity tolerance through ion homeostasis. There is an interpretative difference between the salt-tolerant genotypes of barley (i.e., M4-73-30 and its wild type cv). These two genotypes show the difference in the expression of HVA (202-fold), HvSOS3 (31-fold), HvSOS2 (24-fold), and HvSOS1 (105-fold) genes in the roots of barley. There is more $\mathrm{Na}^{+}$accumulation in wild-type barley sample of shoot than the mutant type. This is because of the less 
transfer of sodium ions from root to shoot in the mutant type which is salt tolerant [130]. Lethin et al. [131] developed a mutant population of wheat with the aim to improve salinity tolerance in wheat. They used Bangladeshi variety BARI Gom-25 which was semi-tolerant to salinity and treating it with EMS (ethyl methanesulfonate) and then compared it with local wheat varieties. After screening, they identified that out of 1676 lines of wheat, 70 lines manifested enhanced salinity tolerance. Results indicated that the mutant lines showed a good salinity tolerance than the local cultivars [131].

\section{Wild relative exploitation}

Interspecific hybridization has a crucial role in ameliorating the crop plant performance for tolerance to several abiotic stresses [132, 133]. Wild relatives of crops are utilized as a source in biotic as well abiotic stress tolerance to increase the crop productivity; however, it requires specialized methods to do so, such as embryo rescue. The salt tolerance source identification as well as the involvement of a candidate gene is a good example found in wild rice germplasm [134-136]. Oryza coarctata, which is a halophytic relative of wild rice, has been studied for tolerance to salt for decades for identification of a way in which it can be utilized in salt tolerance improvement of cultivated rice [136, 137]. Colmer et al. [132] have reappraised the scenarios for salt tolerance improvement in wheat crop by using wild relatives of wheat. Genetic and physical maps as well as genome sequences of wild relatives of some crops are becoming accessible $[138,139]$.

\section{Double haploid (DH)}

Double-haploid production through Anther culture has emerged as an exciting tool for crop improvement having advantages of shortening of the breeding cycle, high selection efficiency, homozygosity fixation, and expression of recessive alleles suitable for breeding. Diploidization of haploid genomes can be produced either by artificial genome doubling (colchicine treatment) or spontaneous genome doubling (endomitosis: chromosome doubling without nucleus division). DH technology was found to be efficient for fixation of favorable alleles controlling agronomically important traits. In rice crop, DH techniques can be utilized for the development of new varieties from photosensitive rice genotypes [140]. Double haploids could emerge as a powerful tool in mapping of QTLs controlling quantitative traits. QTLs linked with sheath blight of rice were identified in a DH population exhibiting resistance against the disease. More than 100 rice breeding varieties have been developed in India, South Korea, the USA, China, and Japan [141]. DH technique produces the homozygous lines of haploid plants by chromosome doubling from sperms or egg cells. Several reviews on DH technology provide an insight to the plant breeders in crop improvement as it has wider application in breeding and genetic study [142, 143]. Al-Ashkar et al. [7] detected salt tolerance of 15 lines of wheat which was developed using DH technique. They analyzed the biochemical as well as physiological parameters and then compared it with wheat check cultivar sakha 93 which is salt tolerant [7].

\section{Marker-assisted breeding (MAB)}

The marker-based selection is an indirect selection process in which the trait of interest is selected on marker basis rather than phenotypic selection. It is the application of molecular biotechnologies, generally molecular markers combined with linkage maps and genomics for the improvement of plant and animal traits that are based on genotypic assays. By increasing the number of markers associated with QTL, could greatly increase the success rate [144, 145]. For efficient marker selection, marker to be used should be close enough to the gene of interest. Molecular markers have become an integral part of the plant breeding and classical genetics. The main reason behind it is that molecular markers made it possible to do selections and breeding for any trait. Earlier, development of molecular markers, linkage map construction, QTL mapping, and fine mapping of precise gene were considered to be labor-intensive and time-consuming processes. But with the advancement of next-generation sequencing (NGS), it has made the development of molecular markers, like simple sequence repeats (SSR), insertion-deletions (InDels), and single-nucleotide polymorphisms (SNPs) easier. The development of these markers has further facilitated the development of high-density genetic maps, which in turn enabled the mapping of target genes. The detection of genetic variation for important agronomic traits is also done using molecular markers. Molecular markers enabled the identification of appropriate parents for molecular breeding and also made it possible to select the desirable offspring at the early developmental stages $[146,147]$. To alleviate the effect of salt on production of rice, new varieties which are salt tolerant are developed using marker-assisted breeding [148-150] and conventional breeding methods [151-153]. MAB is a rapid and accurate method of breeding for introgression of lines or genes. It allocates selection in every breeding cycle for the transfer of gene in a precise manner. MAB also permits restricting the donor region thereby eluding linkage drag [148]. Marker-assisted breeding (MAB) was fortunate in the development of salinity tolerance lines in rice [148, 149, 154-158]. In rice, marker-assisted breeding has been utilized in pyramiding of QTLs which control tolerance against salinity, submergence, as well as 
drought [6]. Pushpavalli et al. [159] studied the chickpea genotypes for salinity tolerance and identified two yieldrelated QTLs in the key genomic region. Comparison with already published chickpea genetic maps showed that these regions conferred salinity tolerance across two other populations, and the markers can be deployed for enhancing salinity tolerance in chickpea.

\section{Genetic engineering for salt tolerance in plants}

Salinity tolerance is predominantly supervised by numerous genes as well as various physiological mechanisms. Genes which are related to salt tolerance provides a presumed postulation of the stress signal network for amplification and enhancing the tolerance of plants to various stresses [160]. The technology of genetic transformation facilitates scientists to attain the transfer of gene in an anticipatory and accurate manner. That is why, scientists' concern is on the plant transformation in order to improve the salt tolerance by operating the osmoprotectant biosynthetic channel for the accumulation of molecules which perform by narrowing the lipid peroxidation, function and structure of protein, ROS scavenging, etc. $[161,162]$. Studies on gene expression by employing constitutive promoters furnish restricted biological information as compared with the use of cell type-specific promoters or inducible promoters. That is why engineering for salt-tolerant crops could be done by miRNA overexpression, using synthetic biology basis in order to enhance strategies for genetic engineering, maintenance of hormone homeostasis to eschew pleiotropic effects, complete knowledge of post-translational modifications, fortunate fine-tuning of response to stress by engineering innovative regulatory targets [163]. Genes which are used for genetic engineering of salt-tolerant crops include water channel proteins, detoxifying genes, dehydrins, osmoprotectants, ion transporter and molecular chaperons (Table 3). In transgenic plants, S-adenosylmethionine decarboxylase (SAMSC) plays an important role in the biosynthesis of PA, and its activities are reported to be enhanced under different salt treatments. Ectopic expression of $S A M D C$-like genes in rice enhanced the level of spm and spd that increased salt tolerance. In addition, the $O s t A$ and $O t s B$, two bifunctional fusion genes derived from $E$. coli in $O$. sativa are reported to increase trehalose content, amino acids under salt stress. According to Li et al. [91], the overexpression of Oryza sativa trehalose phosphate synthase (OSTPS1) shows increased trehalose synthesis and improved salt tolerance in

Table 3 Involvement of genes obtained from different crops and their role in stress tolerance

\begin{tabular}{|c|c|c|c|c|c|c|}
\hline Sr. no. & Gene & Source of gene & Product of gene & Target plant & Effects & References \\
\hline 1 & $A B P 9$ & Zeamays & Transcription factor & Arabidopsis & Salt, cold and drought tolerance & {$[164]$} \\
\hline 2 & TaMYB2A & Triticum aestivum & Transcription factor & Arabidopsis & Salt, cold and drought tolerance & {$[165]$} \\
\hline 3 & TaSRG & Triticum aestivum & Transcription factor & Arabidopsis & Salt tolerance & {$[166]$} \\
\hline 4 & ThNHX1 & Thellungiella halophila & $\mathrm{Na}^{+} / \mathrm{H}^{+}$antiporter & Arabidopsis & Salt tolerance & {$[167]$} \\
\hline 5 & SsNHX2 & Suaeda salsa & $\mathrm{Na}^{+} / \mathrm{H}^{+}$antiporter & Arabidopsis & Salt tolerance & {$[168]$} \\
\hline 6 & PutHKT 2,1 & Puccinellia tenuiflora & $\mathrm{K}^{+}$transporter & Arabidopsis & Salt tolerance & {$[169]$} \\
\hline 7 & $Z m S I M K 1$ & Zea Mays & $\begin{array}{l}\text { Mitogen-activated protein kinase } \\
\text { (MAPK) }\end{array}$ & Arabidopsis & Salt tolerance & {$[170]$} \\
\hline 8 & HVCBF4 & Hordeum vulgare & CBF transcription factor & Rice & $\begin{array}{l}\text { Increased drought, cold and salinity } \\
\text { tolerance }\end{array}$ & {$[171]$} \\
\hline 9 & OSNAC5 & Oryza sativa & Transcription factor & Rice & Salt tolerance & {$[172]$} \\
\hline 10 & CgNHX1 & Chenopodium glaucum & Vacuolar $\mathrm{Na}^{+} / \mathrm{H}^{+}$exchanger & Rice & Increased salt tolerance & {$[173]$} \\
\hline 11 & PgNHX1 & Pennisetum glaucum & Vacuolar $\mathrm{Na}^{+} / \mathrm{H}^{+}$antiporter & Rice & Enhanced salt tolerance & {$[174]$} \\
\hline 12 & OsKAT1 & Oryza sativa & Shaker family $\mathrm{K}^{+}$channel & Rice & Salt tolerance & {$[175]$} \\
\hline 13 & OsBADH & Oryza sativa (Indica) & Betaine aldehyde dehydrogenase & Rice (Japonica) & Enhanced salt tolerance & {$[176]$} \\
\hline 14 & PCINO1 & Porteresia coarctata & Myo-inositol 1-phosphate synthase & Rice, brassica & Salt tolerance & {$[177]$} \\
\hline 15 & MIPS & Spartina alterniflora & Myo-inositol 1-phosphate synthase & Rice, tobacco & Improved salt tolerance & {$[178]$} \\
\hline 16 & AtNHX1 & Arabidopsis thaliana & $\mathrm{Na}^{+} / \mathrm{H}^{+}$antiporter & Maize & Salt tolerance & {$[179]$} \\
\hline 17 & $B A D H$ & Suaeda liaotungensis & Betaine aldehyde dehydrogenase & Maize & Salinity tolerance & {$[175]$} \\
\hline 18 & $\mathrm{H}^{+}$-PPase & Thellungiella halophila & $H(+)$-pyrophosphatase & Cotton & Salt tolerance & {$[180]$} \\
\hline 19 & SbGSTU & Salicornia brachiata & Glutathione S-transferase & Tobacco & Increased salt tolerance & {$[181]$} \\
\hline 20 & AtNHX1 & Arabidopsis & Vacuolar $\mathrm{Na}^{+} / \mathrm{H}^{+}$antiporter & Groundnut & $\begin{array}{l}\text { Enhanced drought and salt toler- } \\
\text { ance }\end{array}$ & {$[182]$} \\
\hline 21 & ThIPK2 & Thellungiella halophila & Inositol poly-phosphate kinase & Brassica napus & Increased abiotic stress tolerance & {$[183]$} \\
\hline 22 & PcSrp & Porteresia coarctata & Serine-rich-protein & Finger millet & Improved salt tolerance & [184] \\
\hline
\end{tabular}


transgenic plants. Similarly, proline and trehalose content were enhanced and upregulation of stress-related genes (responsive to $\mathrm{ABA}(R A B 16 C)$, early light-inducible protein $(E L I P)$, water stress-inducible protein (WSI18), and heat shock protein (HSP70), in transgenic rice.

\section{Novel Approaches in improving salt tolerance CRISPR/Cas9 technique}

CRISPR/Cas9 is an important gene editing tool in which the cas9 protein along with guide RNA from a complex for recognition of target sequences. In the system, the target DNA is cleaved by the Cas9 protein which consists of six domains namely REC1, REC2, Bridge Helix, $\mathrm{HNH}, \mathrm{RuvC}$, and PAM interacting. The Rec1 domain helps in binding the guide RNA, whereas the bridge helix (arginine rich) initiates the cleavage after binding of target DNA. The cas9 protein only activates when bind with guide RNA. The guide RNA is mainly composed of single-stranded RNA with 1 tetraloop and 2 or 3 stem loops, and it must have a 5 ' for complimentary with target DNA sequence. The cas9 protein searches for target DNA for PAM sequences. The protein melts the upstream bases of the PAM and pair with them. In the case of exact target sequence, RuvC and $\mathrm{HNH}$ nuclease play a role to cut the target DNA sequence which then followed by the Watson-crick pairing between the DNA cas9sgRNA complex and guiding sequence $[185,186]$. CRISPR/Cas9 is a precise, systematic, and appropriate method of genome editing which was developed recently [187]. Nowadays, the CRISPR/cas9 technique has been utilized extensively in several crops like maize $[188,189]$, wheat [190, 191], and sorghum [192, 193]. With the help of the CRISPR/Cas9 technology, numerous genes in rice crop such as OsHAK1, OsERF922, OsPDS, TMS5, and Badh2 have been knocked out, and predicted results of phenotype have been obtained [194-197]. Some studies on the elite rice show direct genome editing of cultivar using the CRISPR/Cas9 technique. The gene OsERF922 which is an ERF transcription factor was mutated by this technique to increase the blast resistance in variety Kuiku131 having normal phenotype [190]. Japonica rice cultivar WPB106 was resistant to drought, having good cooking quality and early maturity but sensitive to salt. Its tolerance to salt has been improved by using CRISPR/ cas9 technology where they used the Cas9-OsRR22$g R N A$ expression vector which knocks out the OsRR22 gene. Their results based on this technology illustrated that OsRR22 has an auspicious prospective to advance the amelioration of salinity tolerance in rice breeding [198]. In a study in upland cotton (Gossypium hirsutum) a CRISPR/Cas9-mediated pooled sgRNA assembly was optimized providing a platform in sgRNA designing for targeting the multiple genes. The targeted genes were successfully edited using CRISPR/Cas 9 technique which were related to male sterility in cotton. A total of 112 plant development-related genes were knocked out using this system [199]. Chen et al. [200] successfully generated the first report of generating high-oleic and nontransgenic mutant in allotetraploid upland cotton by knockout of GhFAD2 genes through CRISPR/Cas 9 editing system. Findings in upland cotton suggested that GhFAD2-1A/D is the key gene which determines the fatty acid composition of cottonseed oil.

\section{Hyperspectral imaging (HI)}

Also called imaging spectroscopy, it tells us about how the light interrelate with the materials which measure the quantity of light transmitted, reflected, or emitted [201]. Nowadays, various works emphasize on environmental stress analysis in crops and its related diseases [202, 203]. Hyperspectral imaging is a new technique used to evaluate tolerance to salt stress in wheat crop. There are three methods namely NRD (normalized reflectance difference) curve, posterior stability, and MDPA (minimum difference of pair assignments) which were used to scrutinize hyperspectral images of the lines of wheat crop. They used the four lines of wheat crop namely Kharchia, CS, Co (CS), and Sp (CS). It was concluded that among the four lines, kharchia is more tolerant to salt than the others [204]. HI is a technique used for the identification of material via imaging system providing high spectral resolution when compared with multispectral system, namely Landsat multispectral scanners. This system provides an insight for the improved identification of surface materials especially minerals in soils. HI system is based on the principles of red-green-blue (RGB) image in which an image is presented as a matrix with I rows and J columns providing the I*J dimensions which determine the size of the image. In this system, pixels are fact point measurements, instead of squares, in which each entry in the matrix represents with one pixel [205]. A pixel in an image represents the real space position which is absorbing and reflecting a light across the electromagnetic spectrum. In this system, the reflected light is counted as a number which indicates the intensity. The low intensity of the wavelength is represented by the black image, while high intensity with white and one wavelength showed greyscale image. The color bands lie within the electromagnetic spectrum of light $(400-800 \mathrm{~nm})$ which corresponds to blue, green, and red visible lights [206].

\section{Genome-wide association studies (GWAS)}

GWAS, an important tool, provides an insight in the identification of genotype-phenotype association and is mainly focused on linkage disequilibrium and recombination, and singlefeature polymorphism. In over 1000 
GWAS studies on recombination and linkage disequilibrium [207], single-feature polymorphism [208], pathogen resistance, and early flowering [209] have now been published in plants [210, 211]. GWAS analysis includes the collection of data based on genotypic and phenotypic information in which genotypic data can be collected with the help of microarrays or whole genome sequencing (WGS) or whole exome sequencing (WES). Further, quality control is a major step in the analysis for the deletion of bad single-nucleotide polymorphisms (SNPs) followed by imputation using matched reference populations from repositories. Genetic association tests are conducted for each trait using various models (linear or logistic regression). In silico analysis of GWAS is carried out for in silico fine-mapping, gene to function mapping, genetic correlation, pathway analysis, and SNP to gene mapping [212]. In a study conducted on Oryza sativa using GWAS mapping revealed the novel QTLs at the seedling stage for salinity stress tolerance. GWAS analysis identified 26 QTLs after screening of 179 rice landraces genotyped with 21,623 SNP markers for salinity stress tolerance when treated with $100 \mathrm{mM} \mathrm{NaCl}$ treatment. From the identified QTLs, 10 QTLs were found to be associated with different traits [213]. QTL [214] analyses generally point to particular chromosomal subregions, while the current developed GWASs can recognize accurate location of chromosomes with the intention to elucidate particular genes or polymorphism within the encoding regions $[215,216]$. GWAS studies divulge the candidate genes which underlie characters namely flowering time [217], morphology of root [218], size, shape and length of grain [216], and yield [219] in rice crop. Few studies are there which have applied the technique of GWAS to elucidate the molecular mechanism which induces tolerance [220]. GWAS analyses deliver light on phenotype and protein function when employing suitable population and genotyping of high resolution $[8,221]$. GWAS is used to recognize markers for salt tolerance in rice crop. In this study, they apply GWAS to a diversity which show rice accessions throughout the globe, and these accessions show genetic variability in a high degree. A total of 950 genes were recognized belonging to several functional categories. These genes were overrepresented in Gene ontology (GO) classification of transcription regulation, hydrolase activity, and cation transport [222, 223].

\section{Conclusive remark and future prospects}

On the basis of the physiological, biochemical, as well as molecular aspects, salinity stress tolerance has been extensively studied. Recent studies mainly focused on the molecular basis which acquires more scrutiny. The gene's identification furnishes information regarding the mechanisms which are directly influenced by extracellular cues. Studies on salinity tolerance elucidated that several salinity responses, osmotic regulation, antioxidant metabolism, hormone metabolism, and signalling pathways play a crucial role in stress tolerance. Moreover, new emerging approaches of plant breeding and biotechnologies such as GWAS, mutational breeding, markerassisted breeding (MAB), double haploid production $(\mathrm{DH})$, hyperspectral imaging (HI), and CRISPER/Cas, serve as engineering tools for dissecting the mechanism in more depth. However, understanding of these mechanisms creates a loop of concept for breeders with more focus on plant performance under saline conditions. Moreover, pathways and routes in relation to salinity unravel different components that give exciting outcome to engineer plants for the search of novel salinity resistance genes.

\section{Acknowledgment \\ None}

\section{Authors' contributions}

All the authors have equal contribution in the preparation of manuscript. ST helped in grammar checking; HS helped in editing and styling; AJ helped in figure preparation, whereas UN and AK helped in formatting the manuscript; and MS wrote the manuscript. The authors read and approved the final manuscript.

\section{Funding}

None

Availability of data and materials

NA

\section{Declarations}

Ethics approval and consent to participate

NA

Consent for publication

NA

Competing interests

NA

\section{Author details}

${ }^{1}$ Department of Plant Breeding and Genetics, Punjab Agricultural University, Ludhiana, Punjab 141004, India. ${ }^{2}$ Department of Botany, Punjab Agricultural University, Ludhiana, Punjab 141004, India. ${ }^{3}$ Department of Agronomy, Punjab Agricultural University, Ludhiana, Punjab 141004, India.

Received: 15 June 2021 Accepted: 26 October 2021

Published online: 09 November 2021

\footnotetext{
References

1. Kumar A, Choudhary A, Kaur N, Kaur H (2021a) Wake up-it's time to bloom. Russ J PI Physiol 68:579-595

2. Kumar A, Sharma A, Sharma R, Srivastav P, Choudhary A (2021b) Exploration of wheat wild relative diversity from Lahaul Valley-a cold arid desert of Indian Himalayas. Cereal Res Commun doi.org/https://doi. org/10.1007/s42976-021-00166-w
} 
3. Kumar A, Sharma A, Sharma R, Choudhary A, Srivastava P, Kaur H, Padhy AK (2021c) Morpho-physiological evaluation of Elymus semicostatus (Nees ex Steud.) Melderis as potential donor in wheat (Triticum aestivum L.). Genet Resour Crop Evol. doi.org/https://doi.org/10.1007/ s10722-021-01241-1

4. Kanojia A, Dijkwel PP (2018) Abiotic stress responses are governed by reactive oxygen species and age. Ann Plant Rev:295-326

5. Muthu V, Abbai R, Nallathambi J, Rahman H, Ramasamy S, Kambale R, Muthurajan R (2020) Pyramiding QTLs controlling tolerance against drought, salinity, and submergence in rice through marker assisted breeding. PLoS One 15:e227421

6. Al-Ashkar I, Alderfasi A, El-Hendawy S, Al-Suhaibani N, El-Kafafi S, Seleiman MF (2019) Detecting salt tolerance in doubled haploid wheat lines. Agronomy 9:211

7. Roy B, Noren S, Mandal AB, Basu AK (2011) Genetic engineering for abiotic stress tolerance in agricultural crops. Biotechnol 10:1-22

8. Singh M, Choudhary A, Kumar A, Thapa S (2021) Genetically modified food: their problems and promise. Biotica Res Today 3(2):111-113

9. Kordrostami M, Rahimi M (2015) Molecular markers in plants: concepts and applications. Zhinitik Hizarahi Sivvum. 13:4024-4031

10. USDA-ARS (2008) Research databases. Bibliography on salt tolerance. Brown GE, Jr Salinity Lab. US Dep Agric, Agric Res Serv Riverside, CA

11. Munns R (2002) Comparative physiology of salt and water stress. Plant Cell Environ 25:239-250

12. Rajendran K, Tester M, Roy SJ (2009) Quantifying the three main components of salinity tolerance in cereals. Plant Cell Environ. 32:237-249

13. Li Z, Peng D, Zhang X, Peng Y, Chen M, Ma X, Huang L, Yan Y (2017) $\mathrm{Na}^{+}$ induces the tolerance to water stress in white clover associated with osmotic adjustment and aquaporins-mediated water transport and balance in root and leaf. Environ Exp Bot 144:11-24

14. Vishwakarma K, Upadhyay N, Kumar N, Yadav G, Singh J, Mishra RK, Kumar V, Verma R, Upadhyay RG, Pandey M, Sharma S (2017) Abscisic acid signaling and abiotic stress tolerance in plants: a review on current knowledge and future prospects. Front plant sci 8:161

15. Popova LP, Stoinova ZG, Maslenkova LT (1995) Involvement of abscisic acid in photosynthetic process in Hordeum vulgare L. during salinity stress. J Plant Growth Regul 14:211-218

16. Khan MS, Ahmad D, Khan MA (2015) Utilization of genes encoding osmoprotectants in transgenic plants for enhanced abiotic stress tolerance. Electron J Biotechn 18:257-266

17. Jabeen Z, Hussain N, Irshad F, Zeng J, Tahir A, Zhang G (2020) Physiological and antioxidant responses of cultivated and wild barley under salt stress. Plant Soil Environ 66:334-344

18. Arzani A, Ashraf M (2016) Smart engineering of genetic resources for enhanced salinity tolerance in crop plants. Crit Rev Plant Sci 35(3):146-189

19. Sharp RE, Hsiao TC, Silk WK (1990) Growth of the maize primary root at low water potentials: role of growth and deposition of hexose and potassium in osmotic adjustment. Plant Physiol 93:1337-1346

20. Gupta K, Dey A, Gupta B (2013) Plant polyamines in abiotic stress responses. Acta Physiol Plant 35:2015-2036

21. Choudhary A, Kumar A, Kaur N (2020) ROS and oxidative burst: roots in plant development. Plant Divers 42:33-43

22. Xu J, Xue C, Xue D, Zhao J, Gai J, Guo N, Xing H (2013) Overexpression of $\mathrm{GmH}$ sp90s, a heat shock protein 90 (Hsp90) gene family cloning from soybean, decrease damage of abiotic stresses in Arabidopsis thaliana. PLoS One 8:e69810

23. Pi E, Qu L, Hu J, Huang Y, Qiu L, Lu H, Jiang B, Liu C, Peng T, Zhao Y (2016) Mechanisms of soybean roots' tolerances to salinity revealed by proteomic and phosphoproteomic comparisons between two cultivars. Mol Cell Proteomics 15:266-288

24. Manai J, Kalai T, Gouia H, Corpas FJ (2014) Exogenous nitric oxide (NO) ameliorates salinity-induced oxidative stress in tomato (Solanum lycopersicum) plants. J Soil Sci Plant Nutr 14:433-446

25. Ahmad P, Abdel Latef AA, Hashem A, Abd Allah EF, Gucel S, Tran LSP (2016) Nitric oxide mitigates salt stress by regulating levels of osmolytes and antioxidant enzymes in chickpea. Front Plant Sci 7:347

26. Negrao S, Schmockel S, Tester M (2017) Evaluating physiological responses of plants to salinity stress. Ann Bot 119:1-11

27. Ashraf M, Foolad MR (2007) Roles of glycine betaine and proline in improving plant abiotic stress resistance. Environ Exp Bot 59(2):206-216
28. Xu D, Duan X, Wang B, Hong B, Ho THD, Wu R (1996) Expression of a late embryogenesis abundant protein gene, $\mathrm{HVA} 1$, from barley confers tolerance to water deficit and salt stress in transgenic rice. Plant Physiol 110(1):249-257

29. Juszczak I, Bartels D (2017) LEA gene expression, RNA stability and pigment accumulation in three closely related Linderniaceae species differing in desiccation tolerance. Plant Sci 255:59-71

30. Wahome P, Jesch H, Grittner I (2001) Mechanisms of salt stress tolerance in two rose rootstocks: Rosa chinensis major and Rosa rubiginosa. Sci Horti 87:207-216

31. Parida AK, Das AB, Mohanty P (2004) Investigations on the antioxidative defence responses to $\mathrm{NaCl}$ stress in a mangrove, Bruguiera parviflora: differential regulations of isoforms of some antioxidative enzymes. Plant Growth Regul 42:213-226

32. Shahbaz M, Ashraf M, Akram NA, Hanif A, Hameed S, Joham S, Rehman $R$ (2011) Salt-induced modulation in growth, photosynthetic capacity, proline content and ion accumulation in sunflower (Helianthus annuus L.). Acta Physio Plant 33(4):1113-1122

33. Fang Z, Bouwkamp J, Solomos T (1998) Chlorophyllase activities and chlorophyll degradation during leaf senescence in non-yellowing mutant and wild type of Phaseolus vulgaris L. J Exp Bot 49:503-510

34. Eckardt NA (2009) A new chlorophyll degradation pathway. Plant Cell $21: 700$

35. Forlani G, Bertazzini M, Cagnano G (2018) Stress-driven increase in proline levels, and not proline levels themselves, correlates with the ability to withstand excess salt in a group of 17 Italian rice genotypes. Plant Biol 21:336-342

36. Jeschke WD, Peuke AD, Pate JS, Hartung W (1997) Transport, synthesis and catabolism of abscisic acid (ABA) in intact plants of castor bean (Ricinus communis L.) under phosphate deficiency and moderate salinity. J Exp Bot 48:1737-1747

37. El-Shintinawy F, El-Shourbagy MN (2001) Alleviation of changes in protein metabolism in $\mathrm{NaCl}$-stressed wheat seedlings by thiamine. Biol Plant. 44:541-545

38. Kerepesi I, Galiba G (2000) Osmotic and salt stress-induced alteration in soluble carbohydrate content in wheat seedlings. Crop Sci 40:482-487

39. Lauchli A (1984) Salt exclusion: an adaptation of legumes for crops and pastures under saline conditions. In: Staples RC (ed) Salinity Tolerance in Plants: Strategies for Crop Improvement. Wiley, New York, pp 171-187

40. Ebrahim F, Arzani A, Rahimmalek M, Sun D, Peng J (2020) Salinity tolerance of wild barley Hordeum vulgare ssp. spontaneum. Plant Breed 139(2):304-316

41. Bendaly A, Messedi D, Smaoui A, Ksouri R, Bouchereau A, Abdelly C (2016) Physiological and leaf metabolome changes in the xerohalophyte species Atriplex halimus induced by salinity. Plant Physio Biochem 103:208-218

42. Patel MK, Kumar M, Li W, Luo Y, Burritt DJ, Alkan N, Tran LP (2020) Enhancing salt tolerance of plants: from metabolic reprogramming to exogenous chemical treatments and molecular approaches. Cells 9(11):2492

43. Ishizaki K (2017) Evolution of land plants: insights from molecular studies on basal lineages. Biosci Biotech Bioch 81:73-80

44. Hedrich R, Flügge UI, Fernandez JM (1986) Patch-clamp studies of ion transport in isolated plant vacuoles. FEBS Lett 204:228-232

45. Shu S, Guo SR, Yuan LY (2012) A review: polyamines and photosynthesis. In Najafpour MM, editor. Advances in photosynthesis-fundamental aspects. Intech Rijeka, pp 439-464.

46. Kintzer AF, Stroud RM (2016) Structure, inhibition and regulation of twopore channel TPC1 from Arabidopsis thaliana. Nature 531:258-264

47. Volkmar K, Hu Y, Steppuhn H (1998) Physiological responses of plants to salinity, a review. Can J Plant Sci 78:19-27

48. Nguyen HT, Meir P, Sack L, Evans JR, Oliveira RS, Ball MC (2017) Leaf water storage increases with salinity and aridity in the mangrove Avicennia marina: integration of leaf structure, osmotic adjustment and access to multiple water sources. Plant Cell Environ 40:1576-1591

49. Debez A, Taamalli W, Saadaoui D, Ouerghi Z, Zarrouk M, Huchzermeyer B, Abdelly C (2006) Salt effect on growth, photosynthesis, seed yield and oil composition of the potential crop halophyte Cakile maritima. In: Ozturk M, Waisel Y, Khan MA and Gork G, editors. Biosaline agriculture and salinity tolerance in plants. Birkhauser. Basel, pp 55-63. 
50. Messedi D, Farhani F, Hamed KB, Trabelsi N, Ksouri R, Athar H-u-R, Abdelly C (2016) Highlighting the mechanisms by which proline can confer tolerance to salt stress in Cakile maritima. Pak J Bot 48:417-427

51. Arabbeigi M, Arzani A, Majidi MM (2019) Expression profiles of P5CS and DREB2 genes under salt stress in Aegilops cylindrica. Russ J Plant Physiol 66(4):583-590

52. Akrami M, Arzani A (2019) Inheritance of fruit yield and quality in melon (Cucumis melo L.) grown under field salinity stress. Sci Rep 9(1):1-13

53. Munns R, Tester M (2008) Mechanisms of salinity tolerance. Annu Rev Plant Biol 59:651-681

54. Greenway H, Munns R (1980) Mechanism of salt tolerance in nonhalophytes. Annu Rev Plant Physiol. 31:149-190

55. Shokri-Gharelo R, Noparvar PM (2018) Molecular response of canola to salt stress: insights on tolerance mechanisms. Peer J6:e4822

56. Deinlein U, Stephan AB, Horie T, Luo W, Xu G, Schroeder JI (2014) Plant salt-tolerance mechanisms. Trends Plant Sci 19:371-379

57. Assaha DV, Ueda A, Saneoka H, Al-Yahyai R, Yaish MW (2017) The role of $\mathrm{Na}^{+}$and $\mathrm{K}^{+}$transporters in salt stress adaptation in glycophytes. Front Physiol 8:509

58. De Lourdes Oliveira Otoch M, Menezes Sobreira AC, Farias de Aragao ME (2001) Salt modulation of vacuolar $\mathrm{H}^{+}$-ATPase and $\mathrm{H}^{+}$-pyrophosphatase activities in Vigna unguiculata. J Plant Physiol 158:545-551

59. Dietz KJ, Tavakoli N, Kluge C (2001) Significance of the V-type ATPase for the adaptation to stressful growth conditions and its regulation on the molecular and biochemical level. J Exp Bot 52:1969-1980

60. Segami S, Asaoka M, Kinoshita S, Fukuda M, Nakanishi Y, Maeshima M (2018) Biochemical, structural, and physiological characteristics of vacuolar $\mathrm{H}^{+}$-pyrophosphatase. Plant Cell Physiol 59:1300-1308

61. Keisham M, Mukherjee S, Bhatla SC (2018) Mechanisms of sodium transport in plants-progresses and challenges. Int J Mol Sci 19:647

62. van Zelm E, Zhang Y, Testerink C (2020) Salt tolerance mechanisms of plants. Annu Rev Plant Biol 71:403-433

63. Yang Z, Li J-L, Liu L-N, Xie Q, Sui N (2020) Photosynthetic regulation under salt stress and salt-tolerance mechanism of sweet sorghum. Front Plant Sci 10:1722

64. Jarvis DE, Ryu CH, Beilstein MA, Schumaker KS (2014) Distinct roles for SOS1 in the convergent evolution of salt tolerance in Eutrema salsugineum and Schrenkiella parvula. Mol Biol Evol 31:2094-2107

65. Arabbeigi M, Arzani A, Majidi MM, Sayed-Tabatabaei BE, Saha P (2018) Expression pattern of salt tolerance-related genes in Aegilops cylindrica. Physiol Mol Biol Plants 24(1):61-73

66. Rezaei M, Arzani A, Saeidi G, Karami M (2017) Physiology of salinity tolerance in Bromus danthoniae genotypes originated from saline and non-saline areas of West Iran. Crop Pasture Sci 68(1):92-99

67. Wang WX, Vincour B, Shoseyov O, Altman A (2004) Role of plant heatshock proteins and molecular chaperons in the abiotic stress response. Trends Plant Sci 9:244-252

68. Manaa A, Ben Ahmed H, Valot Bouchet JP, Aschi-Smiti S, Causse M, Faurobert M (2011) Salt and genotype impact on plant physiology and root proteome variations in tomato. J Exp Bot 62:2797-2813

69. Sobhanian H, Aghaei K, Komatsu S (2011) Changes in the plant proteome resulting from salt stress: toward the creation of salt-tolerant crops. J Prot 74:1323-1337

70. Ngara R, Ndimba BK (2014) Understanding the complex nature of salinity and drought-stress response in cereals using proteomics technologies. Proteomics 14:611-621

71. Wang $X$, Zhang H, Shao LY, Yan X, Peng H, Ouyang JX, Li SB (2018) Expression and function analysis of a rice OsHSP40 gene under salt stress. Genes Genom 11:1-8

72. Song H, Zhao R, Fan P, Wang X, Chen X, Li Y (2009) Overexpression of AtHsp90. 2, AtHsp90. 5 and AtHsp90. 7 in Arabidopsis thaliana enhances plant sensitivity to salt and drought stresses. Planta 229:955-964

73. Muthusamy SK, Dalal M, Chinnusamy V, Bansal KC (2016) Differential regulation of genes coding for organelle and cytosolic Clp ATPases under biotic and abiotic stresses in wheat. Front Plant Sci 7:929

74. Cen H, Wang T, Liu H, Tian D, Zhang Y (2020) Melatonin application improves salt tolerance of alfalfa (Medicago sativa L.) by enhancing antioxidant capacity. Plants 9:220
75. Zhai H, Wang F, Si Z, Huo J, Xing L, An Y, He S, Liu Q (2016) A myo-inositol-1-phosphate synthase gene, IbMIPS1, enhances salt and drought tolerance and stem nematode resistance in transgenic sweet potato. Plant Biotechnol J 14:592-602

76. Mishra D, Shekhar S, Singh D, Chakraborty S, Chakraborty N, (2018) Heat shock proteins and abiotic stress tolerance in plants. In: Asea AAA, Kaur P (eds) Regulation of Heat Shock Protein Responses, Heat Shock Proteins vol 13. Springer, Cham, p 41-69.

77. Hay RT (2005) SUMO: a history of modification. Mol Cell 18:1-12

78. Conti L, Price G, O'Donnell E, Schwessinger B, Dominy P, Sadanandom A (2008) Small ubiquitin-like modifier proteases overly tolerant to Salt1 and -2 regulate salt stress responses in Arabidopsis. Plant Cell 20:2894-2908

79. Srivastav AK, Zhang C, Yates G, Bailey M, Brown A, Sadanandom (2016) A SUMO is a critical regulator of salt stress responses in rice. Plant Physiol 170:2378-2391

80. Xu C, Wu X, Zhang H (2009) Impact of D-Arg on drought resistance and endogenous polyamines in mycorrhizal Pinus massoniana. J Nanjing Forest Uni 33:19-23

81. Vuosku J, Karppinen K, Muilu-Mäkelä R, Kusano T, Sagor GHM, Avia K (2018) Scot's pine aminopropyltransferases shed new light on evolution of the polyamine biosynthesis pathway in seed plants. Annu Bot 121:1243-1256

82. Knott JM, Romer P, Sumper M (2007) Putative spermine synthases from Thalassiosira pseudonana and Arabidopsis thaliana synthesize thermospermine rather than spermine. FEBS Lett 581:3081-3086

83. Hussain SS, Ali M, Ahmad M, Siddique KHM (2011) Polyamines: natural and engineered abiotic and biotic stress tolerance in plants. Biotechnol Adv 29:300-311

84. Hasanuzzaman M, Nahar K, Fujita M (2014) Regulatory role of polyamines in growth, development and abiotic stress tolerance in plants. In: Plant adaptation to environmental change: significance of amino acids and their derivatives. CAB ebooks. CABI, Wallingford, pp 157-193

85. Meng D, Hou L, Yang S (2015) Exogenous polyamines alleviating salt stress on peanuts (Arachis hypogaea) grown in pots. Chin J Plant Ecol 39:1209-1215

86. Baniasadi F, Saffari VR, Moud AAM (2018) Physiological and growth responses of Calendula officinalis $L$. plants to the interaction effects of polyamines and salt stress. Sci Horti 234:312-317

87. Wang Q, Bo Y (2014) Alleviative effects of different kinds of exogenous polyamines on salt injury of soybean seedlings. J Henan Agri Sci 43:48-50

88. Paul S, Roychoudhury A (2017) Seed priming with spermine and spermidine regulates the expression of diverse groups of abiotic stress responsive genes during salinity stress in the seedlings of indica rice varieties. Plant Gene 11:124-132

89. Sun L, Yu S, Zhao F (2018) Effects of salt stress on polyamines and hormone metabolism in grape seedlings. Xinjiang Agri Sci 55:66-73

90. McLoughlin F, Testerink C (2013) Phosphatidic acid, a versatile waterstress signal in roots. Front. Plant Sci. 4:525

91. Li C-H, Wang G, Zhao J-L, Zhang L-Q, Ai L-F et al (2014) The receptor-like kinase SIT1 mediates salt sensitivity by activating MAPK3/6 and regulating ethylene homeostasis in rice. Plant Cell 26:2538-2553

92. Mittler R (2002) Oxidative stress, antioxidants and stress tolerance. Trends Plant Sci 7:405-410

93. Ma L, Zhang H, Sun L (2012) NADPH oxidase AtrbohD and AtrbohF function in $\mathrm{ROS}$-dependent regulation of $\mathrm{Na}^{+} / \mathrm{K}^{+}$homeostasis in Arabidopsis under salt stress. J Exp Bot 63:305-317

94. Liu C, Mao B, Ou S (2014) OsbZIP71, a bZIP transcription factor, confers salinity and drought tolerance in rice. Plant Mol Biol 84:19-36

95. Begara-Morales JC, Sanchez-Calvo B, Chaki C (2014) Dual regulation of cytosolic ascorbate peroxidase (APX) by tyrosine nitration and S-nitrosylation. J Exp Bot 65:527-538

96. Agarwal S, Shaheen R (2007) Stimulation of antioxidant system and lipid peroxidation by abiotic stresses in leaves of Momordica charantia. Braz J Plant Physiol 19:149-161

97. Munir N, Aftab F (2011) Enhancement of salt tolerance in sugarcane by ascorbic acid pre-treatment. Afr J Biotechnol 10:18362-18370

98. Liu B, Peng X, Han L, Hou L, Li B (2020) Effects of exogenous spermidine on root metabolism of cucumber seedlings under salt stress by GC-MS. Agronomy 10:459 
99. Pi E, Zhu C, Fan W, Huang Y, Qu L, Li Y, Zhao Q, Ding F, Qiu L, Wang H, Poovaiah BW (2018) Quantitative phosphoproteomic and metabolomic analyses reveal GmMYB173 optimizes flavonoid metabolism in soybean under salt stress. Mol Cell Proteomics 17(6):1209-1224

100. Xu Z, Zhou J, Ren T, Du H, Liu H, Li Y, Zhang C (2020) Salt stress decreases seedling growth and development but increases quercetin and kaempferol content in Apocynum venetum. Plant Biol 22:813-821

101. Oliveira DM, Mota TR, Salatta FV, Sinzker RC, Končitíková R, Kopečný D, Simister R, Silva M, Goeminne G, Morreel K, Rencoret J (2020) Cell wall remodeling under salt stress: insights into changes in polysaccharides, feruloylation, lignification, and phenolic metabolism in maize. Plant Cell Environ 43(9):2172-2191

102. Gavaghan CL, Li JV, Hadfield ST, Hole S, Nicholson JK, Wilson ID, Howe PW, Stanley PD, Holmes E (2011) Application of NMR-based metabolomics to the investigation of salt stress in maize (Zea mays). Phytochem. Anal 22:214-224

103. Siddiqui MH, Alamri S, Al-Khaishany MY, Khan MN, Al-Amri A, Ali HM, Alaraidh IA, Alsahli AA (2019) Exogenous melatonin counteracts NaClinduced damage by regulating the antioxidant system, proline and carbohydrates metabolism in tomato seedlings. Int J Mol Sci 20:353

104. Quan WL, Liu X, Wang HQ, Chan ZL (2016) Physiological and transcriptional responses of contrasting alfalfa (Medicago sativa L.) varieties to salt stress. Plant Cell Tissue Organ Cult 126:105-115

105. Anower RM, Mott IW, Peel MD, Wu Y (2013) Characterization of physiological responses of two alfalfa half-sib families with improved salt tolerance. Plant Physiol Biochem 71:103-111

106. Kiani R, Arzani A, Mirmohammady Maibody SAM (2021) Polyphenols, flavonoids, and antioxidant activity involved in salt tolerance in wheat, Aegilops cylindrica and their amphidiploids. Front Plant Sci 12:493

107. Choudhary A, Kumar A, Kaur N, Paul A (2020) Plasmodesmata the nano bridges in plant cell: are the answer for all the developmental processes? Russ J Plant Physiol 67:785-796

108. Luo M, Liu X, Singh CY, Zimmerli L, Wu K (2012) Chromatin modifications and remodeling in plant abiotic stress responses. Biochim Biophys Acta 1819:129-136

109. Lang L, Xu A, Ding J, Zhang Y, Zhao N, Tian Z, Liu Y, Wang Y, Liu X, Liang $F$, Zhang B (2017) Quantitative trait locus mapping of salt tolerance and identification of salt-tolerant genes in Brassica napus L. Front Plant Sci 8:1000

110. Sairam RK, Tyagi A (2004) Physiology and molecular biology of salinity stress tolerance in plants. Current Sci. 86:407-421

111. Shi H, Quintero FJ, Pardo JM, Zhu JK (2002) The putative plasma membrane $\mathrm{Na}^{+} / \mathrm{H}^{+}$antiporter SOS1 controls long-distance $\mathrm{Na}^{+}$transport in plants. Plant Cell 14:465-477

112. Liu J, Ishitani M, Halfter U (2000) The Arabidopsis thaliana SOS2 gene encodes a protein kinase that is required for salt tolerance. Proc. Natl Acad Sci USA 97:3730-3734

113. Ishitani M, Liu J, Halfter U, Kim CS, Shi W, Zhu JK (2000) SOS3 function in plant salt tolerance requires $\mathrm{N}$-myristoylation and calcium binding. Plant Cell 12:1667-1677

114. Schmidt R, Mieulet D, Hubberten HM (2013) Salt-responsive ERF1 regulates reactive oxygen species-dependent signaling during the initial response to salt stress in rice. Plant Cell 25:2115-2131

115. Fukuda A, Tanaka Y (2006) Effects of ABA, auxin, and gibberellin on the expression of genes for vacuolar $\mathrm{H}^{+}$-inorganic pyrophosphatase, $\mathrm{H}^{+}$-ATPase subunit $\mathrm{A}$, and $\mathrm{Na}^{+} / \mathrm{H}^{+}$antiporter in barley. Plant Physiol Biochem 44:351-358

116. Keskin BC, Sarikaya AT, Yuksel B, Memon AR (2010) Abscisic acid regulated gene expression in bread wheat (Triticum aestivum L.). Australian J Crop Sci 48(2010):617-625

117. Nakashima K, Shinwari ZK, Sakuma Y, Seki M, Miura S, Shinozaki K, Yamaguchi-Shinozaki K (2000) Organization and expression of two Arabidopsis DREB2 genes encoding DRE-binding proteins involved in dehydration-and high-salinity-responsive gene expression. Plant Mol bio 42(4):657-665

118. Niu CF, Wei W, Zhou QY, Tian AG, Hao YJ, Zhang WK (2012) Wheat WRKY genes TaWRKY2 and TaWRKY19 regulate abiotic stress tolerance in transgenic Arabidopsis plants. Plant Cell Env 35:1156-1170

119. Diedhiou CJ (2006) Mechanisms of salt tolerance: sodium, chloride and potassium homeostasis in two rice lines with different tolerance to salinity stress. PhDThesis, University of Bielefeld.
120. Ghomi K, Rabiei B, Sabouri H, Sabouri A (2013) Mapping QTLs for traits related to salinity tolerance at seedling stage of rice (Oryza sativa L.): an agrigenomics study of an Iranian rice population. OMICS 17:242-251

121. Kordrostami M, Rabiei B, Kumleh HH (2016) Association analysis, genetic diversity and haplotyping of rice plants under salt stress using SSR markers linked to SalTol and morpho-physiological characteristics. Plant Sys. Evol. 302:871-890

122. Asghari R, Ahmadvand R (2018) Salinity stress and its impact on morpho-physiological characteristics of aloe vera. Pertanika J Trop Agri Sci 41:411-422

123. Ashraf MY, Wu L (1994) Breeding for salinity tolerance in plants. Crit Rev Plant Sci 13(1):17-42

124. Arzani A (2008) Improving salinity tolerance in crop plants: a biotechnological view. Vitro Cell Dev Biol Plant 44(5):373-383

125. Flowers JL, Jacobs S, Cho E, Morton A, Rosenberger WF, Evans D et al (1997) Comparison of open and laparoscopic live donor nephrectomy. Ann Surg 226(4):483

126. Ismail AM, Horie T (2017) Genomics, physiology, and molecular breeding approaches for improving salt tolerance. Annu Rev Plant Biol 68:405-434

127. Deshmukh R, Sonah H, Patil G, Chen W, Prince S, Mutava R, Vuong T, Valliyodan B, Nguyen HT (2014) Integrating omic approaches for abiotic stress tolerance in soybean. Front Plant sci 5:244

128. Forster BP, Shu QY (2012) Plant mutagenesis in crop improvement: basic terms and applications. In: Shu QY, Forster BP, Nakagawa H (eds) Plant mutation breeding and biotechnology. CABI, Wallingford, pp 9-20

129. Oladosu Y, Rafii MY, Abdullah N, Hussin G, Ramli A, Rahim HA, Usman M (2016) Principle and application of plant mutagenesis in crop improvement: a review. Biotech Equi 30(1):1-16

130. Yousefirad S, Soltanloo H, Ramezanpour SS, Zaynalinezhad K, Shariati $\checkmark$ (2018) Salt oversensitivity derived from mutation breeding improves salinity tolerance in barley via ion homeostasis. Biol Plant 62:775-785

131. Lethin J, Shakil SS, Hassan S, Sirijovski N, Töpel M, Olsson O, Aronsson H (2020) Development and characterization of an EMS-mutagenized wheat population and identification of salt-tolerant wheat lines. BMC Plant Biol 20:18

132. Colmer TD, Flowers TJ, Munns R (2006) Use of wild relatives to improve salt tolerance in wheat. J Exp Bot 57:1059-1078

133. Atwell B, Wang H, Scafaro AP (2014) Could abiotic stress tolerance in wild relatives of rice be used to improve Oryza sativa? Plant Sci 215:48-58

134. Mishra S, Singh B, Misra P, Rai V, Singh NK (2016) Haplotype distribution and association of candidate genes with salt tolerance in Indian wild rice germplasm. Plant Cell Rep 35:2295

135. Mishra S, Singh B, Panda K, Singh BP, Singh N, Misra P, Rai V, Singh NK (2016a) Association of SNP haplotypes of HKT family genes with salt tolerance in Indian wild rice germplasm. Rice 9(1):1-3

136. Flowers TJ, Flowers SA, Hajibagheri MA, Yeo AR (1990) Salt tolerance in the halophytic wild rice, Porteresia coarctata Tateoka. New Phytol 114:675-684

137. Garg R, Verma M, Agrawal S, Shankar R, Majee M, Jain M (2013) Deep transcriptome sequencing of wild halophyte rice, Porteresia coarctata, provides novel insights into the salinity and submergence tolerance factors. DNA Res 21:69-84

138. Consort TG (2012) The tomato genome sequence provides insights into fleshy fruit evolution. Nature 485:635-641

139. Wing RA, Ammiraju JSS, Luo M, Kim H, Yu Y (2005) The Oryza Map Alignment Project: the golden path to unlocking the genetic potential of wild rice species. Plant Mol Biol 59:56-62

140. Samantaray S, Jauhar Ali KL, Katara JL, Verma RL, Parameswaran C, Devanna BN, Kumar A, Dash B, Bhuyan SS (2021) Doubled haploids in rice improvement: approaches, applications, and future prospects. Rice Improv 425

141. Siddique R (2015) Impact of different media and genotypes in improving anther culture response in rice (Oryza sativa) in Bangladesh. Eur Sci J 11(6)

142. Dwivedi SL, Britt AB, Tripathi L, Sharma S, Upadhyaya HD, Ortiz R (2015) Haploids: constraints and opportunities in plant breeding. Biotechnol Adv 33:812-829 
143. Murovec J, Bohanec B (2012) "Haploids and doubled haploids in plant breeding," in Plant Breeding, ed I. Abdurakhmonov (Rijeka: Intech), 87-106.

144. Singh, M., Nara, U., Kumar, A., Thapa, S., Jaswal, C., \& Singh, H. (2021). Enhancing genetic gains through marker-assisted recurrent selection: from phenotyping to genotyping. Cereal Research Communications, 1-16.

145. Han B, Wang C, Tang Z, Ren Y, Li Y, Zhang D, Dong Y, Zhao X (2015) Genome-wide analysis of microsatellite markers based on sequenced database in Chinese spring wheat (Triticum aestivum L.). PLoS One 10:e0141540

146. Heffner EL, Jannink J, Sorrells ME (2011) Genomic selection accuracy using multifamily prediction models in a wheat breeding program. Plant Genome 4:65-75

147. Jiang GL (2013) Molecular markers and marker-assisted breeding in plants. Plant breeding from laboratories to fields, pp 45-83

148. Singh R, Singh Y, Xalaxo S, Verulkar S, Yadav N, Singh S (2016) From QTL to variety - harnessing the benefits of QTLs for drought, flood and salt tolerance in mega rice varieties of India through a multi-institutional network. Plant Sci 242:278-287

149. Babu NN, Vinod KK, Krishnamurthy SL, Krishnan SG, Yadav A, Bhowmick PK (2017) Microsatellite based linkage disequilibrium analyses reveal Saltol haplotype fragmentation and identify Novel QTLs for seedling stage salinity tolerance in rice. J Plant Biochem Biotechnol 26:310-320

150. Geetha S, Vasuki A, Jagadeesh SP, Saraswathi R, Krishnamurthy SL, Manikandan MP (2017) Development of sodicity tolerant rice varieties through marker assisted backcross breeding. Electron J Plant Breed 8:1013-1021

151. Krishnamurthy SL, Sharma PC, Gautam RK, Singh RK, Singh YP, Mishra VK (2019) Notification of crop varieties and registration of germplasm: variety CSR56 (IET 24537). Indian J Genet Plant Breed 79:512-513

152. Krishnamurthy SL, Sharma PC, Gautam RK, Singh RK, Singh YP, Mishra VK (2019) Notification of crop varieties and registration of germplasm: variety CSR60. Indian J Genet Plant Breed 79:513-514

153. Krishnamurthy SL, Sharma PC, Singh YP, Gautam RK, Singh RK, Sharma DK (2019) Notification of crop varieties and registration of germplasm: variety CSR46 (IET 18710). Indian J Genet Plant Breed 79:511-512

154. Singh VK, Singh BD, Kumar A, Maurya S, Krishnan SG, Vinod KK, Singh MP, Ellur RK, Bhowmick PK, Singh AK (2018) Marker-assisted introgression of Saltol QTL enhances seedling stage salt tolerance in the rice variety "Pusa Basmati 1". Int J Genomics.

155. Linh LH, Linh TH, Xuan TD, Ham LH, Ismail AM, Khanh TD (2012) Molecular breeding to improve salt tolerance of rice (Oryza sativa L.) in the Red River Delta of Vietnam. Int J Plant Breed Genet.

156. Luu TNH, Luu MC, Ismail AM, Ham LH (2012) Introgression of the salinity tolerance QTLs Saltol into AS996, the elite rice variety of Vietnam. Am J Plant Sci 3:981-987

157. Usatov A, Alabushev AV, Kostylev PI, Azarin KV, Makarenko MS, Usatova OA (2015) Introgression the SalTol QTL into the elite rice variety of Russia by marker-assisted selection. Am J Plant Sci 10:165-169

158. Bhandari A, Jayaswal P, YadavN SR, Singh Y, Singh B (2019) Genomicsassisted backcross breeding for infusing climate resilience in high yielding green revolution varieties of rice. Indian J Genet Plant Breed 79:160-170

159. Pushpavalli R, Krishnamurthy L, Thudi M, Gaur PM, Rao MV, Siddique KH et al (2015) Two key genomic regions harbour QTLs for salinity tolerance in ICCV $2 \times J G 11$ derived chickpea (Cicer arietinum L.) recombinant inbred lines. BMC Plant Biol 15(1):1-15

160. Liang W, Ma X, Wan P, Liu L (2018) Plant salt-tolerance mechanism: a review. Biochem Biophys Res Commun 495:286-291

161. Abogadallah GM (2010) Antioxidative defense under salt stress. Plant Signal Behav 5:369-374

162. Saxena SC, Kaur H, Verma P, Petla BP, Andugula VR, Majee M (2013) Osmoprotectants: potential for crop improvement under adverse conditions. In: Tuteja N, Gill SS (eds) Plant acclimation to environmental stress. Springer, New York, pp 197-232

163. Cabello JV, Lodeyro AF, Zurbriggen MD (2014) Novel perspectives for the engineering of abiotic stress tolerance in plants. Curr Opin Biotechnol 26:62-70

164. Zhang $X$, Wang L, Meng H, Wen H, Fan Y, Zhao J (2011) Maize ABP9 enhances tolerance to multiple stresses in transgenic Arabidopsis by modulating ABA signaling and cellular levels of reactive oxygen species. Plant Mol Biol 75:365-378

165. Mao X, Jia D, Li A, Zhang H, Tian S, Zhang X, Jia J, Jing R (2011) Transgenic expression of TaMYB2A confers enhanced tolerance to multiple abiotic stresses in Arabidopsis. Funct Integr Genomic 11:445

166. He X, Hou X, Shen Y, Huang Z (2011) TaSRG, a wheat transcription factor, significantly affects salt tolerance in transgenic rice and Arabidopsis. FEBS Lett 585:1231-1237

167. Wu C, Gao X, Kong X, Zhao Y, Zhang H (2009) Molecular cloning and functional analysis of a $\mathrm{Na}^{+} / \mathrm{H}^{+}$antiporter gene ThNHX1 from a halophytic plant Thellungiella halophila. Plant Mol Biol Rep 27:1-12

168. Li WH, Zhang Q, Kong XQ, Wu CX, Ma XL, Zhang H, Zhao YX (2009) Salt tolerance is conferred in Arabidopsis by over-expression of the vacuolar $\mathrm{Na}^{+} / \mathrm{H}^{+}$antiporter gene $\mathrm{SsNHX} 2$, an alternative splicing variant of SsNHX1, from Suaeda salsa. J Plant Biol 52:147-153

169. Ardie AW, Xie LN, Takahashi R, Liu SK, Takano T (2009) Cloning of a high-affinity $\mathrm{K}^{+}$transporter gene PutHKT2, 1 from Puccinellia tenuiflora and its functional comparison with OsHKT2, 1 from rice in yeast and Arabidopsis. J Exp Bot 60:3491-3492

170. Gu L, Liu Y, Zong X, Liu L, Li DP, Li DQ (2010) Overexpression of maize mitogen-activated protein kinase gene, ZmSIMK1 in Arabidopsis increases tolerance to salt stress. Mol Biol Rep 37:4067-4073

171. Oh SJ, Chang-Woo Kwon CW, Dong-Woog Choi DW, Sang IK, Song SI, Kim JK (2007) Expression of barley HvCBF4 enhances tolerance to abiotic stress in transgenic rice. Plant Biotechnol J. 5(2007):646-656

172. Takasaki H, Maruyama K, Kidokoro S, Fujita Y, Shinozaki K, YamaguchiShinozaki K, Nakashima K (2010) The abiotic stress-responsive NAC-type transcription factor OsNAC5 regulates stress-inducible genes and stress tolerance in rice. Mol Genet Genomic 284:73-83

173. Li JY, He XW, Xu L, Zhou J, Wu P, Shou HX, Zhang FC (2008) Molecular and functional comparisons of the vacuolar $\mathrm{Na}^{+} / \mathrm{H}^{+}$exchangers originated from glycophytic and halophytic species. J Zhejiang Univ Sci B 9:132-140

174. Verma D, Singla-Pareek SL, Rajagopal D, Reddy MK, Sopory SK (2007) Functional validation of a novel isoform of $\mathrm{Na}^{+} / \mathrm{H}^{+}$antiporter from Pennisetum glaucum for enhancing salinity tolerance in rice. J Biosci 32(6):21-628

175. Obata T, Kitamoto HK, Nakamura A, Fukuda A, Tanaka Y (2007) Rice shaker potassium channel OsKAT1 confers tolerance to salinity stress on yeast and rice cells. Plant Physiol 144:1978-1985

176. Wu W, Su Q, Xia XY, Wang Y, Luan YS, An LJ (2008) The Suaeda liaotungensis kitag betaine aldehyde dehydrogenase gene improves salt tolerance of transgenic maize mediated with minimum linear length of DNA fragment. Euphytica 159:17-25

177. Das-Chatterjee A, Goswami L, Maitra S, Ghosh-Dastidar K, Ray S, Majumder AL (2006) Introgression of a novel salt-tolerant L-myoinositol 1-phosphate synthase from Porteresia coarctata (Roxb.) Tateoka (PCINO1) confers salt tolerance to evolutionary diverse organisms. FEBS Lett 580:3980-3988

178. Baisakh N, Rajasekharan K, Deleon T, Biradar H, Parco A, Singh P, Subudhi PK (2009) Overexpression of myo-inositol phosphate synthase gene from a halophyte Spartina alterniflora confers salt tolerance in transgenic tobacco and rice. Plant and Animal Genome XVII, San Diego, CA, Jan 10-14 2009, Poster No. 616, Final abstract guide, p 117.

179. Li TX, Zhang Y, Liu H, Wu YT, Li WB, Zhang HX (2010) Stable expression of Arabidopsis vacuolar $\mathrm{Na}^{+} / \mathrm{H}^{+}$antiporter gene AtNHX1, and salt tolerance in transgenic soyabean for over six generations. Chin Sci Bull. 55:1127-1134

180. Lv S, Zhang KW, Gao Q, Lian LJ, Song YJ, Zhang JR (2008) Overexpression of an $\mathrm{H}^{+}$-PPase gene from Thellungiella halophila in cotton enhances salt tolerance and improves growth and photosynthetic performance. Plant Cell Physiol 49:1150-1164

181. Jha B, Sharma A, Mishra A (2010) Expression of SbGSTU (tau class glutathione S-transferase) gene isolated from Salicornia brachiata in tobacco for salt tolerance. Mol Biol Rep 38:4823-4832

182. Asif MA, Zafar Y, lqbal J, lqbal MM, Rashid U, Ali GM, Arif A, Nazir F (2011) Enhanced expression of AtNHX1 in transgenic groundnut (Arachis hypogaea L.) improves salt and drought tolerance. Mol Biotechnol 49(2011):250-256

183. Zhu JQ, Zhang JT, Tang RJ, Lv QD, Wang QQ, Yang L, Zhang HX (2009) Molecular characterization of ThIPK2, an inositol poly-phosphate kinase 
gene homolog from Thellungiella halophila, and its heterologous expression to improve abiotic stress tolerance in Brassica napus. Physiol Plant 136:407-425

184. Mahalakshmi S, Christopher GSB, Reddy TP, Rao KV, Reddy VD (2006) Isolation of a cDNA clone (PCSrp) encoding serine-rich-protein from Porteresia coarctata $L$. and its expression in yeast and finger millet (Eleusine coracana L.) affording salt tolerance. Planta 224:347-359

185. Sternberg SH, LaFrance B, Kaplan M, Doudna JA (2015) Conformational control of DNA target cleavage by CRISPR Cas9. Nature 527:110

186. Singh D, Sternberg SH, Fei J, Doudna JA (2016) Real-time observation of DNA recognition and rejection by the RNA-guided endonuclease Cas9. Nat commun 7:12778

187. Shan Q, Wang Y, Li J, Zhang Y, Chen K, Liang Z, Zhang K, Liu J, Xi JJ, Qiu JL, Gao C (2013) Targeted genome modification of crop plants using a CRISPR-Cas system. Nat Biotechnol 31:686-688

188. Svitashev S, Schwattz C, Lenderts B, Young JK, Cigan AM (2016) Genome editing in maize directed by CRISPR-Cas9 ribonucleoprotein complexes. Nat Commun 7:13274

189. Zhu J, Song N, Sun S, Yang W, Zhao H, Song W, Lai J (2016) Efficiency and inheritance of targeted mutagenesis in maize using CRISPR-Cas9. J Genet Genom 43:25-36

190. Wang F, Wang C, Liu P, Lei C, Hao W, Gao Y, Liu YG, Zhao K (2016) Enhanced rice blast resistance by CRISPR/Cas9-targeted mutagenesis of the ERF transcription factor gene OsERF922. PLoS One 11:e0154027

191. Liang Z, Chen KL, Li TD, Zhang Y, Wang YP, Zhao Q, Liu JX, Zhang HW, Liu CM, Ran YD, Gao CX (2017) Efficient DNA-free genome editing of bread wheat using CRISPR/Cas9 ribonucleoprotein complexes. Nat Commun. 8:14261

192. Cai Y, Chen L, Liu X, Sun S, Wu C, Jiang B, Han T, Hou W (2015) CRISPR/ Cas9-mediated genome editing in soybean hairy roots. PLoS One 10:e0136064

193. Li Z, Liu ZB, Xing A, Moon BP, Koellhoffer JP, Huang L, Ward RT, Clifton E, Falco SC, Cigan AM (2015) Cas9-guide RNA directed genome editing in soybean. J Plant Physiol 169:960-970

194. Zhang H, Zhang J, Wei P, Zhang B, Gou F, Feng Z, Mao Y, Yang L, Zhang $\mathrm{H}, \mathrm{Xu}$ N, Zhu JK (2014) The CRISPR/Cas9 system produces specific and homozygous targeted gene editing in rice in one generation. Plant Biotechnol J. 12:797-807

195. Zhou H, He M, Li J, Chen L, Huang Z, Zheng S, Zhu L, Ni E, Jiang D, Zhao B, Zhuang C (2016) Development of commercial thermo-sensitive genic male sterile rice accelerates hybrid rice breeding using the CRISPR/Cas9-mediated TMS5 editing system. Sci Rep 6:37395

196. Nieves-Cordones M, Mohamed S, Tanoi K, Kobayashi NI, Takagi K, Vernet A, Guiderdoni E, Périn C, Sentenac H, Véry AA (2017) Production of low$\mathrm{Cs}^{+}$rice plants by inactivation of the $\mathrm{K}^{+}$transporter OsHAK1 with the CRISPR-Cas system. Plant J 92:43-56

197. Shao GN, Xie LH, Jiao GA, Wei XJ, Sheng ZH, Tang S (2017) CRISPR/ CAS9-mediated editing of the fragrant gene Badh2 in rice. Chi J Rice Sci 31(2):16-222

198. Zhang A, Liu Y, Wang F, Li T, Chen Z, Kong D et al (2019) Enhanced rice salinity tolerance via CRISPR/Cas9-targeted mutagenesis of the OsRR22 gene. Mol Breed 39:47

199. Ramadan M, Alariqi M, Ma Y, Li Y, Liu Z, Zhang R et al (2021) Efficient CRISPR/Cas9 mediated pooled-sgRNAs assembly accelerates targeting multiple genes related to male sterility in cotton. Plant Methods 17(1):1-13

200. Chen Y, Fu M, Li H, Wang L, Liu R, Liu Z, Jin S (2021) High-oleic acid content, nontransgenic allotetraploid cotton (Gossypium hirsutum L.) generated by knockout of GhFAD2 genes with CRISPR/Cas9 system. Plant Biotech J 19(3):424

201. Goetz AFH, Vane G, Solomon JE, Rock BN (1985) Imaging spectrometry for Earth remote sensing. Science 228:1147-1153

202. Strachan IB, Pattey E, Boisvert JB (2002) Impact of nitrogen and environmental conditions on corn as detected by hyperspectral reflectance. Remote Sens Environ 80:213-224

203. Feng W, Qi S, Heng Y, Zhou Y, Wu Y, Liu W et al (2017) Canopy vegetation indices from in situ hyperspectral data to assess plant water status of winter wheat under powdery mildew stress. Front Plant Sci 8:1219
204. Moghimi A, Yang C, Miller ME, Kianian SF, Marchetto PM (2018) A novel approach to assess salt stress tolerance in wheat using hyperspectral imaging. Front Plant Sci 9:1182

205. Grahn H, Geladi P (2007) Techniques and applications of hyperspectral image analysis: John Wiley \& Sons, Chichester.

206. Faltynkova A, Johnsen G, Wagner M (2021) Hyperspectral imaging as an emerging tool to analyze microplastics: a systematic review and recommendations for future development. Microplastics Nanoplastics 1(1):1-19

207. Kim S, Plagnol V, Hu TT, Toomajian C, Clark RM, Ossowski S et al (2007) Recombination and linkage disequilibrium in Arabidopsis thaliana. Nat Genet 39(9):1151-1155

208. Borevitz JO, Hazen SP, Michael TP, Morris GP, Baxter IR, Hu TT et al (2007) Genome-wide patterns of single-feature polymorphism in Arabidopsis thaliana. Proc Natl Acad Sci 104(29):12057-12062

209. Aranzana MJ, Kim S, Zhao K, Bakker E, Horton M, Jakob K et al (2005) Genome-wide association mapping in Arabidopsis identifies previously known flowering time and pathogen resistance genes. PLoS Genet 1(5):e60

210. Fernie AR, Gutierrez-Marcos J (2019) From genome to phenome: genome-wide association studies and other approaches that bridge the genotype to phenotype gap. Plant J 97(1):5-7

211. Liu HJ, Yan J (2019) Crop genome-wide association study: a harvest of biological relevance. Plant J 97(1):8-18

212. Alseekh S, Kostova D, Bulut M, Fernie AR (2021) Genome-wide association studies: assessing trait characteristics in model and crop plants. Cell Mol Life Sci:1-12

213. Le TD, Gathignol F, Vu HT, Nguyen KL, Tran LH, Vu HTT, Véry AA (2021) Genome-wide association mapping of salinity tolerance at the seedling stage in a panel of Vietnamese landraces reveals new valuable QTLs for salinity stress tolerance breeding in rice. Plants 10:1088

214. Pandit A, Rai V, Bal S, Sinha S, Kumar V, Chauhan M, Gautam R (2010) Combining QTL mapping and transcriptome profiling of bulked RILS for identification of functional polymorphism for salt tolerance genes in rice (Oryza sativa L.). Mol Genet Genomic 284:121-136

215. Korte A, Farlow A (2013) The advantages and limitations of trait analysis with GWAS: a review. Plant method 9:29

216. Si L, Chen J, Huang X, Gong H, Luo J, Hou Q, Zhou T (2016) OsSPL13 controls grain size in cultivated rice. Nat Genet 48:447-456

217. Zhao K, Tung CW, Eizenga GC, Wright MH, Ali ML, Price AH, Norton GJ (2011) Genome-wide association mapping reveals a rich genetic architecture of complex traits in Oryza sativa. Nat commun 2:467

218. Biscarini F, Cozzi P, Casella L, Riccardi P, Vattari A, Orasen G, Perrini R (2016) Genome-wide association study for traits related to plant and grain morphology, and root architecture in temperate rice accessions. PLoS One 11:e0155425

219. Liang S, Wu L, Ren G, Zhao X, Zhou M, Mcneil D, Ye G (2016) Genomewide association study of grain yield and related traits using a collection of advanced indica rice breeding lines for irrigated ecosystems. Field Crops Res 193:70-86

220. Kumar V, Singh A, Mithra SA, Krishnamurthy S, Parida SK, Jain S, Tiwari KK (2015) Genome-wide association mapping of salinity tolerance in rice (Oryza sativa). DNA Res. 22:133-145

221. Mc Couch SR, Wright MH, Tung CW, Maron LG, Mcnally KL, Fitzgerald M, Singh N (2016) Open access resources for genome-wide association mapping in rice. Nat communi 7:1-14

222. Singh $H$, Singh $M$, Jaswal C (2021) Antitranspirant: a novel emerging approach to combat drought stress in maize (Zea mays L.). Biotica Res Today 3(1):068-069

223. Patishtan J, Hartley TN, Fonseca de Carvalho R, Maathuis FJ (2018) Genome-wide association studies to identify rice salt-tolerance markers. Plant Cell Environ. 41:970-982

\section{Publisher's Note}

Springer Nature remains neutral with regard to jurisdictional claims in published maps and institutional affiliations. 